\title{
High-resolution water column survey to identify active sublacustrine hydrothermal discharge zones within Lake Rotomahana, North Island, New Zealand
}

\author{
Sharon L. Walker ${ }^{\mathrm{a}, *}$, Cornel E.J. de Ronde ${ }^{\mathrm{b}}$, Daniel Fornari ${ }^{\mathrm{c}}$, Maurice A. Tivey ${ }^{\mathrm{c}}$, Valerie K. Stucker ${ }^{\mathrm{b}}$ \\ a Pacific Marine Environmental Laboratory (PMEL), National Oceanic E Atmospheric Administration, Seattle, WA, USA \\ ${ }^{\mathrm{b}}$ Marine Geosciences, GNS Science, Lower Hutt, New Zealand \\ c Woods Hole Oceanographic Institution, Woods Hole, MA, USA
}

\section{A R T I C L E I N F O}

\section{Article history:}

Received 2 April 2015

Accepted 31 July 2015

Available online 12 August 2015

\section{Keywords:}

Lake Rotomahana

Hydrothermal venting

$\mathrm{pH}$

Turbidity

Oxidation-reduction potential

Freshwater lakes

\begin{abstract}
A B S T R A C T
Autonomous underwater vehicles were used to conduct a high-resolution water column survey of Lake Rotomahana using temperature, $\mathrm{pH}$, turbidity, and oxidation-reduction potential (ORP) to identify active hydrothermal discharge zones within the lake. Five areas with active sublacustrine venting were identified: (1) the area of the historic Pink Terraces; (2) adjacent to the western shoreline subaerial "Steaming Cliffs," boiling springs and geyser; (3) along the northern shoreline to the east of the Pink Terrace site; (4) the newly discovered Patiti hydrothermal system along the south margin of the 1886 Tarawera eruption rift zone; and (5) a location in the east basin (northeast of Patiti Island). The Pink Terrace hydrothermal system was active prior to the 1886 eruption of Mount Tarawera, but venting along the western shoreline, in the east basin, and the Patiti hydrothermal system appear to have been initiated in the aftermath of the eruption, similar to Waimangu Valley to the southwest. Different combinations of turbidity, $\mathrm{pH}$ anomalies (both positive and negative), and ORP responses suggest vent fluid compositions vary over short distances within the lake. The seasonal period of stratification limits vertical transport of heat to the surface layer and the hypolimnion temperature of Lake Rotomahana consequently increases with an average warming rate of $\sim 0.010^{\circ} \mathrm{C}$ /day due to both convective hydrothermal discharge and conductive geothermal heating. A sudden temperature increase occurred during our 2011 survey and was likely the response to an earthquake swarm just 11 days prior.
\end{abstract}

Published by Elsevier B.V.

\section{Introduction}

Hydrothermal venting in deep freshwater lakes has been discovered and studied in detail at only a few locations worldwide, including Lake Baikal, Siberia (Crane et al., 1991); Crater Lake, Oregon, USA (Dymond et al., 1989); Yellowstone Lake, Wyoming, USA (Remsen et al., 1990; Morgan et al., 2003); Lake Tanganyika, East Africa (Tiercelin et al., 1993); and Lake Taupo, North Island, New Zealand (de Ronde et al., 2002). In each of these cases, the tectonic and volcanic setting of the lakes, areas of high heat flow through the sediments, observations of water temperature anomalies, and/or presence of gas bubble plumes were the basis for SCUBA, ROV, or manned submersible explorations to locate individual sites of active venting on the lake beds.

Lake Rotomahana lies at the southern edge of the Haroharo caldera within the Okataina Volcanic Center as part of the larger Taupo Volcanic Zone, North Island, New Zealand (Fig. 1), and was significantly modified

\footnotetext{
* Corresponding author at: NOAA/PMEL, 7600 Sand Point Way NE, Bldg\#3, Seattle, WA, USA. Tel.: + 12065266788 .

E-mail address: Sharon.L.Walker@noaa.gov (S.L. Walker).
}

by the violent phreatomagmatic phase of the eruption of Mount Tarawera on June 10, 1886. Prior to the 1886 eruption, Rotomahana (or "warm lake") was a small, shallow lake with numerous geothermal features along its shorelines, including the hot springs and geysers of the famed Pink and White Terraces. Lake Rotomakariri ("cold lake") was located nearby. Volcanic and hydrothermal explosions along the 17-km-long eruption fissure left a large steaming crater in place of lakes Rotomahana and Rotomakariri (Keam, 2016) and created a new geothermal field, Waimangu Valley, to the southwest. The Rotomahana crater re-filled with water during the following 15 years forming one larger, deeper lake that is present-day Lake Rotomahana. Waimangu Valley has provided a unique opportunity to observe and monitor the post-eruption evolution of both the geothermal features and the ecology of the area. However, unlike Waimangu Valley, the post-eruption evolution of the area submerged by Lake Rotomahana has been hidden from view.

Hydrothermal input into Lake Rotomahana has been inferred from elevated sediment temperatures and heat flow measurements (Whiteford and Graham, 1993, 1994), and from observations that the bottom water (hypolimnion) of Lake Rotomahana is on average $3-5{ }^{\circ} \mathrm{C}$ warmer than the bottom water of nearby lakes of similar depth 


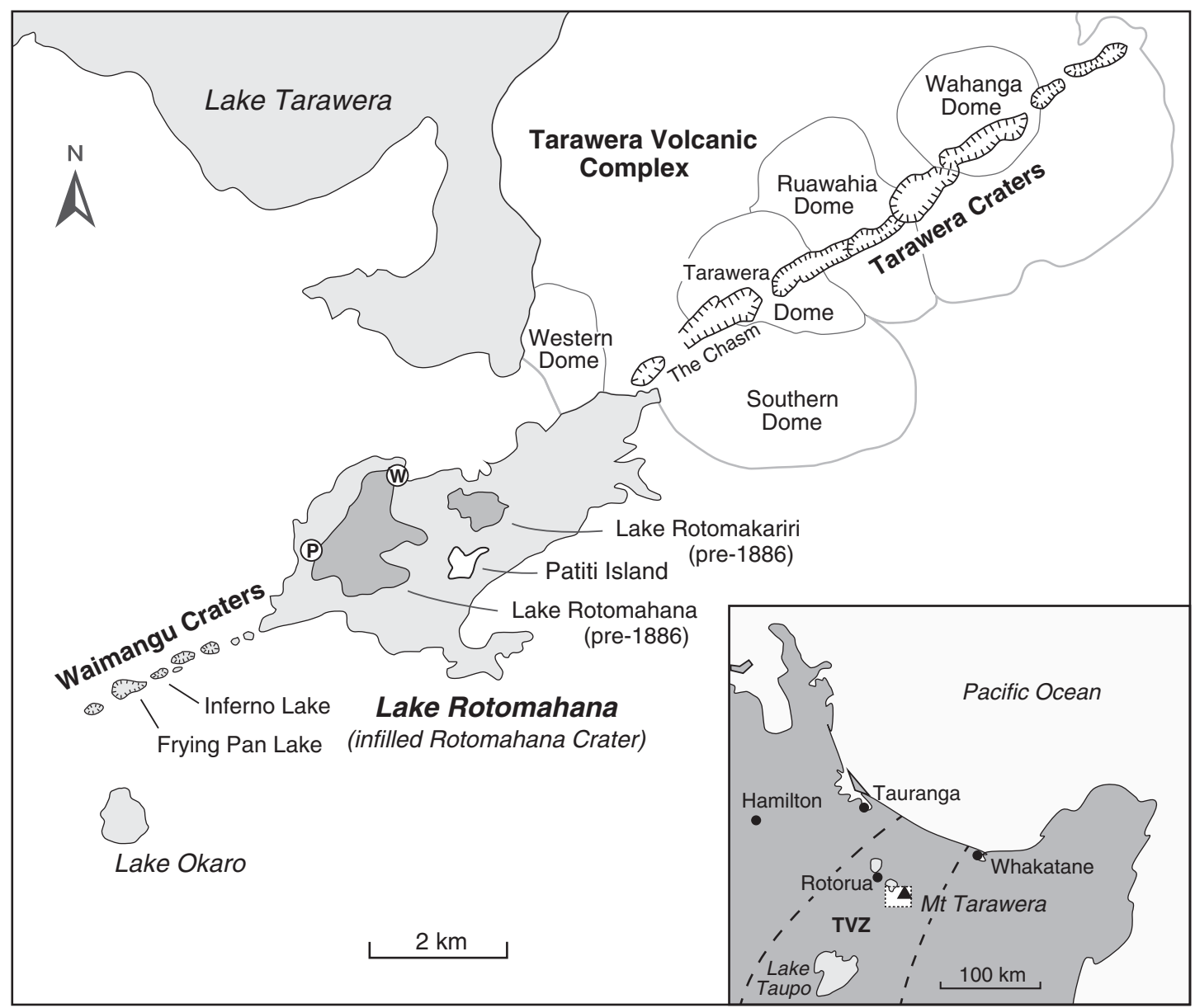

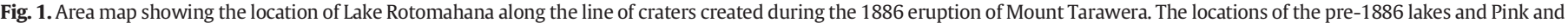

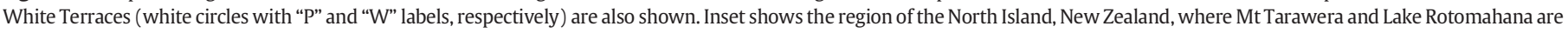
located (white box) within the approximate boundaries of the Taupo Volcanic Zone (TVZ).

and size (Irwin, 1968; Jolly, 1968). While one study measured much warmer temperatures within $1 \mathrm{~m}$ of the lake floor $(\sim 80 \mathrm{~m}$ water depth) in a limited area southwest of Patiti Island (Irwin, 1968), and discolored water and bubbles have been observed at the surface at a few near-shore locations (Nairn, 1989), the distribution of active hydrothermal venting beneath Lake Rotomahana remained unknown. A systematic survey in January 2011 using echo sounding equipment identified over 100 locations where bubble plumes could be seen rising from the lake bed (Mazot et al., 2014; de Ronde et al., 2016). Gas composition indicated a magmatic origin; however, this survey did not determine how many of these bubble plumes were accompanied by warm water.

This study is part of a larger multidisciplinary program to understand the current state of the Waimangu-Rotomahana geothermal system and the impact the 1886 Tarawera eruption had on it. We describe here the results of a detailed water column survey that mapped the distribution of temperature, $\mathrm{pH}$, oxidation-reduction potential (ORP), and turbidity to identify currently active hydrothermal discharge zones in Lake Rotomahana. These physical and chemical parameters have been used extensively to explore for sites of active hydrothermal activity on the seafloor (Baker et al., 2008, 2012; de Ronde et al., 2001, 2007; German et al., 2008), but this is the first time these water column sensors have been integrated with autonomous underwater vehicles (AUV) to measure key hydrothermal tracers along closely spaced tracklines to spatially define areas of active hydrothermal venting within a deep volcanic lake.

\section{Regional setting}

\subsection{Thermal structure of Lake Rotomahana}

The thermal and density structure in Lake Rotomahana follows a warm monomictic pattern (Hutchinson, 1957): the lake never freezes and is always warmer than $4{ }^{\circ} \mathrm{C}$; cooling and vertical mixing create an isothermal water column once a year during the winter months (June through August); and a thermally stratified water column forms from September through May with a thermocline (region of rapidly decreasing temperature) depth of about $25 \mathrm{~m}$ (Jolly, 1968; Irwin, 1968). During periods of stratification, temperature below the thermocline decreases more slowly with depth $\left(0.02{ }^{\circ} \mathrm{C} / \mathrm{m}\right)$ to a depth of about $50-60 \mathrm{~m}$ and is nearly isothermal (decrease by $<0.002{ }^{\circ} \mathrm{C} / \mathrm{m}$ ) between $60 \mathrm{~m}$ depth and the lake bottom. The maximum depth of Lake Rotomahana is $118 \mathrm{~m}$ (de Ronde et al., 2016).

Lake Rotomahana is sampled regularly by Bay of Plenty Regional Council to monitor water quality and determine ecosystem management requirements. Full-depth temperature profiles from 1990 to 2008 are available from Lake Ecosystem Restoration New Zealand (LERNZ; http://www.lernz.co.nz/research-themes/lakes/rotorua-lakesdatabase) and provide nearly two decades of historic context for the temperature changes observed during this study.

The annual and seasonal variability of temperature in the surface (epilimnion) and deep (hypolimnion) water of Lake Rotomahana are shown in Fig. 2 (LERNZ database, 1990-2008). Surface water temperature varies 

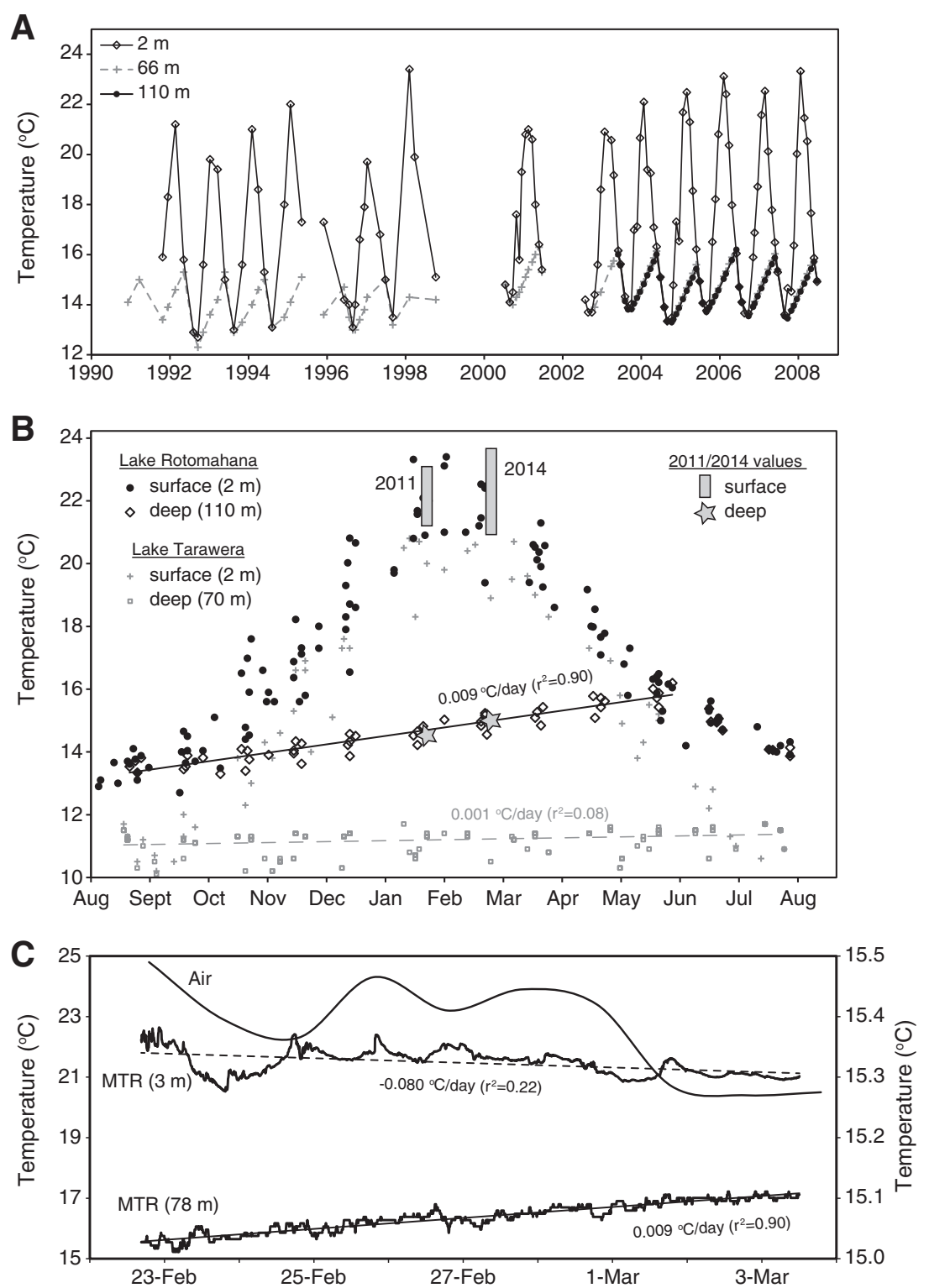

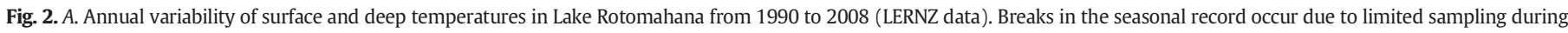

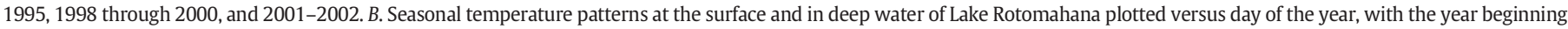

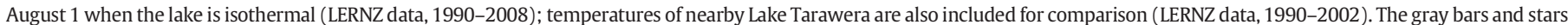

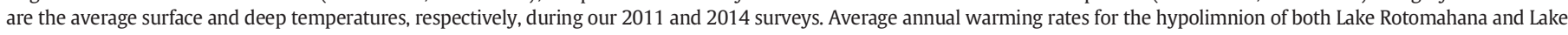

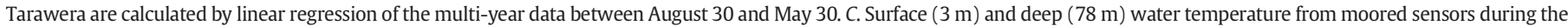
2014 survey period; air temperature from meteorological records (NIWA, CliFlo database, Rotorua Aero AWS, station no. 1770).

with air temperature throughout the year with maximum temperatures occurring around February. Temperature in the hypolimnion begins increasing when the lake stratifies in late August/early September and continues warming through the end of May when the water column becomes isothermal again.

A comparison between Lake Rotomahana and nearby Lake Tarawera (LERNZ database, 1990-2002) demonstrates the significance of geothermal heating to Lake Rotomahana (Fig. 2B). Lake Rotomahana is warmer than Lake Tarawera throughout the year, with a maximum difference between surface temperatures of $\sim 3^{\circ} \mathrm{C}$ during the winter and a maximum difference of temperatures in their hypolimnions of $\sim 4-5{ }^{\circ} \mathrm{C}$ by the end of May. Linear regression of the multi-year data returns a seasonal warming rate for the deep waters of Lake Rotomahana of $0.009^{\circ} \mathrm{C} /$ day with a high correlation coefficient $\left(\mathrm{r}^{2}=0.90\right)$ compared to $0.001{ }^{\circ} \mathrm{C} /$ day and very low correlation coefficient $\left(r^{2}=0.08\right)$ for Lake Tarawera. When each season (September-May) between 1990 and 2008 is analyzed separately for Lake Rotomahana, the average warming rate is $0.010{ }^{\circ} \mathrm{C} / \mathrm{day} \pm 0.001{ }^{\circ} \mathrm{C}$ (Table 1 ). Changes in temperature of this magnitude are noticeable over the course of several days. For example, Whiteford and Bibby (1995) reported a warming rate of $0.011 \pm 0.003{ }^{\circ} \mathrm{C} /$ day observed during a 9-day sampling period in October 1992.

\subsection{Thermal springs in Waimangu Valley}

The hot springs, geysers, and mud pools of Waimangu Valley have been characterized as near-neutral pH high chloride fluids in most places, with steam-heated acidic fluids at Inferno Crater and Cathedral Rocks mud pools (Sheppard, 1986; Timperly and Brown, 1986; Simmons et al., 1993). Prior to the 1886 Tarawera eruption, the Pink Terraces were fed by large chloride springs, and other features around the original Lake Rotomahana included boiling chloride springs, steaming ground, and acid mud pools (Sheppard, 1986). Today, geothermal manifestations such as geysers, boiling springs, and fumaroles 
Table 1

Seasonal (September through May) warming rates in Lake Rotomahana hypolimnion (1990-2008).

\begin{tabular}{ll}
\hline Date & $\left({ }^{\circ} \mathrm{C} /\right.$ day $)$ \\
\hline $1990-1991$ & 0.009 \\
$1991-1992$ & 0.010 \\
$1992-1993$ & 0.012 \\
$1993-1994$ & 0.008 \\
$1994-1995$ & 0.010 \\
$1995-1996$ & $\mathrm{nd}^{1}$ \\
$1996-1997$ & 0.013 \\
$1997-1998$ & 0.007 \\
$1998-1999$ & $\mathrm{nd}^{1}$ \\
$1999-2000$ & $\mathrm{nd}^{1}$ \\
$2000-2001$ & 0.010 \\
$2001-2002$ & $\mathrm{nd}^{1}$ \\
$2002-2003$ & 0.010 \\
$2003-2004$ & 0.010 \\
$2004-2005$ & 0.010 \\
$2005-2006$ & 0.009 \\
$2006-2007$ & 0.010 \\
$2007-2008$ & 0.009 \\
Ave $=$ & 0.010 \\
Stdev $=$ & 0.001 \\
\hline 1 nd = not enough data to determine warming \\
trend for the season.
\end{tabular}

occur along the lakeshore, especially on the western end of the lake (Keywood et al., 1992). Chemical analyses indicate that the source for fluids venting at the Rotomahana shoreline features and Waimangu Valley hot springs is the same deep geothermal reservoir having an estimated temperature between 200 and $230{ }^{\circ} \mathrm{C}$, with different surface characteristics attributed to different pathways, dilution factors, and residence times between the deep source and the surface (Stucker et al., 2016). A similar range of fluid compositions and venting styles can be expected for sublacustrine hydrothermal discharge within Lake Rotomahana.

\section{Methods}

The high-resolution water column survey of Lake Rotomahana was completed from 24 January to 02 February 2011, with follow-up sampling from 22 February to 07 March 2014. Two REMUS-100 autonomous underwater vehicles (AUVs) completed 18 missions during the 2011 survey. Each AUV was equipped with a pH sensor (Seabird Electronics, Inc. Model 18, resolution 0.003 pH units), and a PMEL Miniature Autonomous Plume Recorder (MAPR) to measure temperature ( $0.001{ }^{\circ} \mathrm{C}$ resolution), pressure, turbidity, and ORP. The AUVs covered a total linear distance of $\sim 250 \mathrm{~km}$ along lines spaced $20-50 \mathrm{~m}$ apart while maintaining an altitude of $10-15 \mathrm{~m}$ above the lake bed (Fig. 3A). Average AUV velocity was $1.4 \mathrm{~m} / \mathrm{s}$ resulting in a $\mathrm{pH}$ measurement every $1.4 \mathrm{~m}$ (sample rate $=1 \mathrm{~s}$ ) and temperature, turbidity, and ORP measurements every $7 \mathrm{~m}$ (sample rate $=5 \mathrm{~s}$ ). Turbidity is reported in nephelometric turbidity units (NTU; American Public Health Association, 1985).

The AUV missions were supplemented with 14 CTD (conductivitytemperature-depth) profiles in 2011 and 17 profiles in 2014 (Fig. 3B). Specific conductance is related to the total dissolved ions of a fluid and is derived from conductivity normalized to $25^{\circ} \mathrm{C}$. The CTD also included sensors to measure turbidity (optical backscatter) and ORP. Niskin bottles were attached to the cable to collect water samples at up to 4 discrete, pre-determined depths during each profile (see Stucker et al., 2016).

The lake temperature was also monitored at seven depths $(3,13,20$, $38,58,78,98 \mathrm{~m}$ ) for 9 days during our 2014 survey using an array of temperature sensors (MTR; resolution $=0.0007{ }^{\circ} \mathrm{C}$ at $15^{\circ} \mathrm{C}$ ) moored near the southwest end of the lake (Fig. 3B; Tivey et al., 2016).

\section{Identification of anomalies}

\subsection{Identifying temperature anomalies}

The vertical and temporal variability of temperature in Lake Rotomahana makes identifying temperature anomalies associated with hydrothermal input challenging due to constantly changing "background" values. Lake-floor discharge of hydrothermal fluids (i.e., vents) may occur at any depth $(0-118 \mathrm{~m})$ into the vertically and seasonally variable thermal structure of the lake, and dilution of vented fluids within a short distance from the source will significantly reduce temperature gradients that define anomalies. The density of geothermal fluids is determined by the opposing effects of warmer water, which lowers density, plus added dissolved solids (salinity), which increases density, so above-bottom plumes will only be present when the density difference between vented fluids and ambient lake water is sufficient to generate a noticeable rise height (i.e., the fluids are buoyant). Using sensors with high resolution allows us to identify local changes in temperature on the order of millidegrees. Anomalies are quantified relative to temperatures immediately before and after an anomalous signal at a constant depth. Given the factors noted above, temperature anomalies, when present, constrain locations of active venting to nearby sources.

\subsection{Identifying chemical and turbidity anomalies}

Based on the fluid composition of geothermal features in Waimangu Valley, and some limited data from hot springs prior to the 1886 Tarawera eruption (Sheppard, 1986; Simmons et al., 1994), characteristics of fluids entering Lake Rotomahana may range from neutral or alkaline chloride waters to acidic steam. As with temperature, $\mathrm{pH}$ varies with depth. Surface layer values range from 7.6 to 8 , then decrease through the thermocline to average hypolimnion values of 6.5-6.7 due to high levels of dissolved $\mathrm{CO}_{2}$ (Timperly and Brown, 1986; Mazot et al., 2014; Stucker et al., 2016). Identifying anomalous pH also relies on comparing values relative to other values at similar locations and depths rather than assigning one "background" value.

The ORP sensor is highly sensitive to reduced chemical species common in hydrothermal fluids such as $\mathrm{Fe}(\mathrm{II}), \mathrm{H}_{2} \mathrm{~S}$, and $\mathrm{H}_{2}$, and responds to the presence of these species with a decrease in potential ( $\Delta \mathrm{E}=$ negative; Walker et al., 2007). These species are reactive and often short-lived, so ORP anomalies indicate "younger" more reduced fluids close to a source. The sensor also responds to dissolved $\mathrm{CO}_{2}$ with a slight increase in potential $(\Delta \mathrm{E}=$ positive; $\mathrm{S}$. L. Walker, unpublished data). Because absolute values of the ORP sensor (E, mv) are subject to instrumental drift and hysteresis, we use the total change of the sensor response $(\Delta \mathrm{E})$ or the time derivative $(\mathrm{dE} / \mathrm{dt})$ to quantify anomalies (Nakamura et al., 2000; Walker et al., 2008).

The epilimnion of Lake Rotomahana has increased turbidity (1$1.5 \mathrm{NTU}$ ) relative to the hypolimnion, which has a fairly constant value of $\sim 0.3 \mathrm{NTU}$ below the thermocline. Increases in turbidity above these background values ( $\triangle \mathrm{NTU})$ can be due to resuspension, runoff, increased biological productivity, or other causes. However, a local increase in turbidity that is also correlated with temperature, $\mathrm{pH}$, and/or ORP anomalies is a strong indicator of nearby active hydrothermal venting of source fluids that are enriched in dissolved minerals that precipitate upon mixing with colder ambient water.

\section{Results}

The average surface and deep water temperatures measured during our 2011 and 2014 surveys are included in Fig. 2B. The hypolimnion was warmer in 2014 than 2011; however, the values fall within the seasonal temperature pattern for the dates of our surveys. Data from the surface ( $3 \mathrm{~m}$ ) and deep (78 m) moored temperature sensors in 2014 are shown in Fig. 2C. Surface temperature generally varied with daily maximum air temperature (NIWA CliFlo database, Rotorua Aero AWS, station no. 

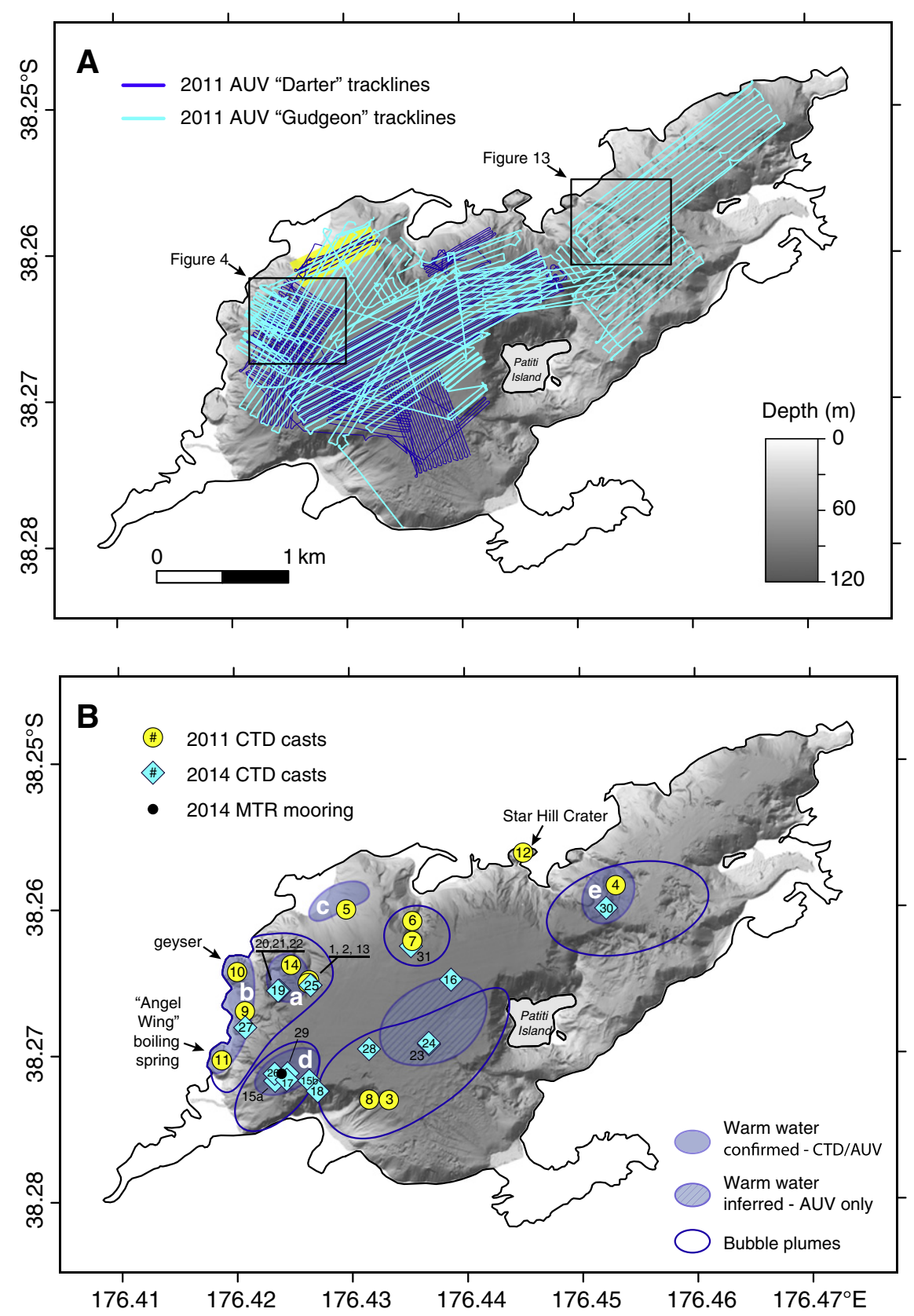

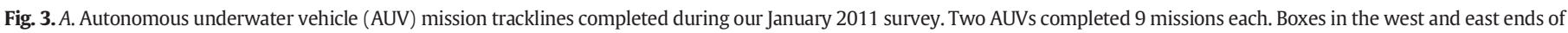

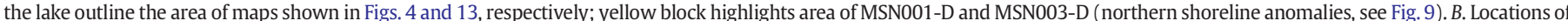

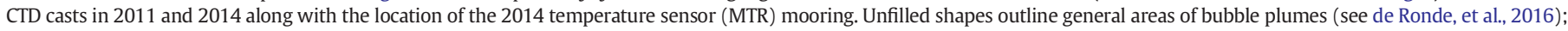

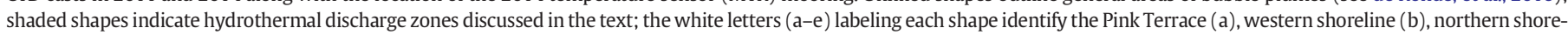
line (c), Patiti (d), and east basin (e) hydrothermal zones.

1770), and decreased from $22.5^{\circ} \mathrm{C}$ to $21^{\circ} \mathrm{C}$ between 22 February and 03 March 2014. Meanwhile, temperature in the hypolimnion increased by $0.08{ }^{\circ} \mathrm{C}$, a rate of $0.009{ }^{\circ} \mathrm{C} /$ day $\left(r^{2}=0.90\right)$, consistent with the multi-year average seasonal warming rate. Hypolimnion warming during the early part of our 2011 survey was also consistent with the multi-year warming rate, but a greater, and sudden, increase was noticeable on January 29, 2011, which will be discussed in detail below.

Five areas with active hydrothermal discharge were identified from these surveys (Fig. 3B) including (a) the area of the historic Pink Terraces; (b) adjacent to the western shoreline "Steaming Cliffs," boiling springs and geyser; (c) along the northern shoreline to the east of the Pink Terrace site; (d) the newly identified Patiti hydrothermal system along the southern margin of the 1886 Tarawera eruption rift zone (see de Ronde et al., 2016); and (e) a location in the east basin (i.e., northeast of Patiti Island).

\subsection{Pink Terrace area}

Fig. 4A shows pH along the trackline of "Darter" mission MSN007-D. Water depth in this area ranges from $23 \mathrm{~m}$ (the lower edge of the thermocline) in the SW corner of the grid to over $100 \mathrm{~m}$ in the SE corner of the grid. Both positive and negative $\mathrm{pH}$ anomalies are present in this area (Fig. 4). The positive anomalies ( $+0.12 \mathrm{pH}$ units at $55 \mathrm{~m}$ ) are located along a ridge on the northeast side of this survey box. The negative anomalies $(-0.06 \mathrm{pH}$ units) are located at multiple depths $(78,50$, and $25-30 \mathrm{~m}$ ) along the face of the steep cliff on the south west side of the box. 


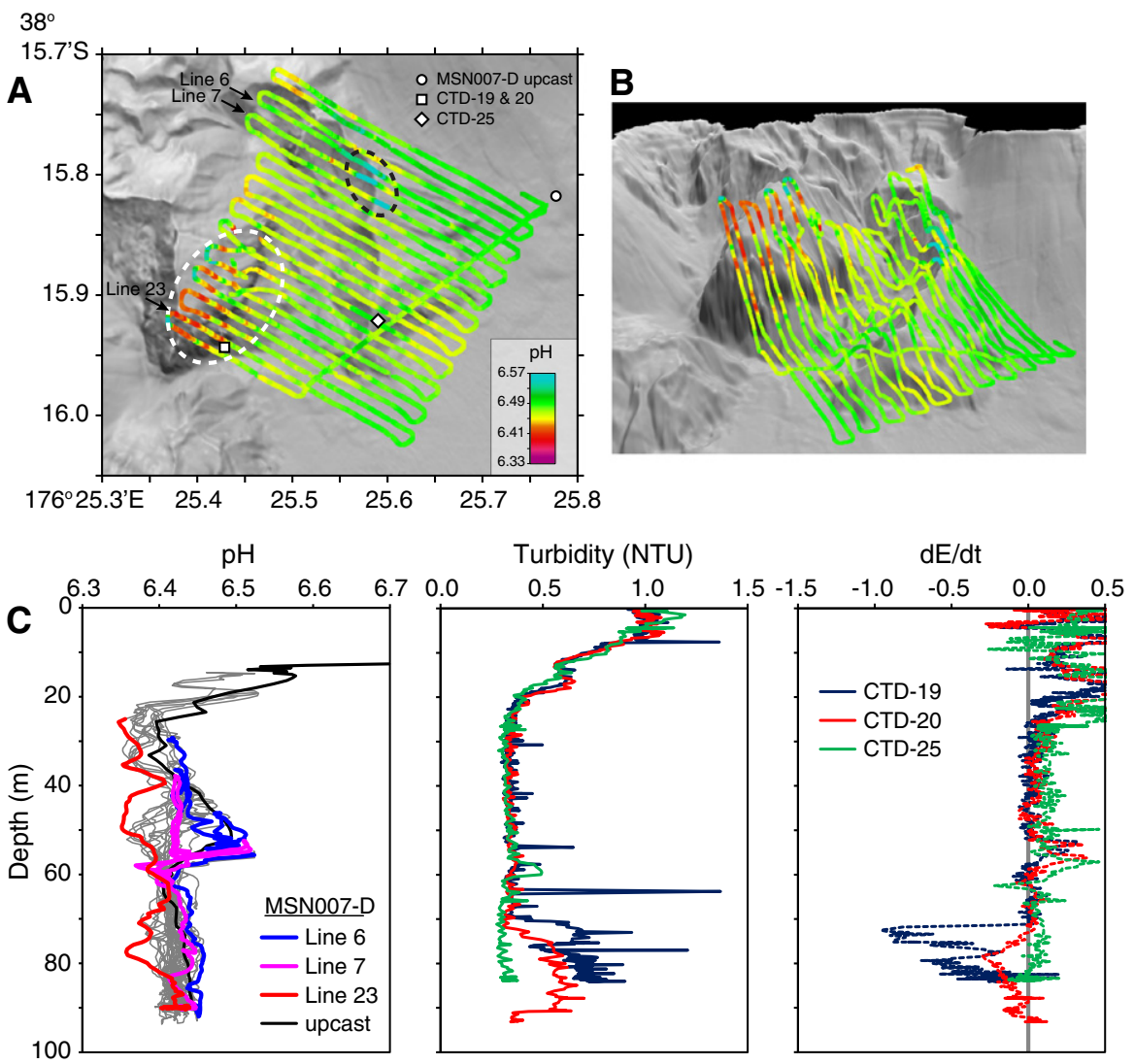

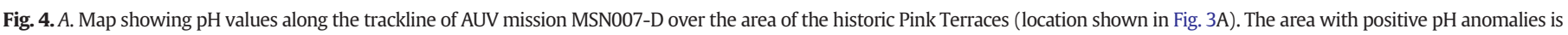

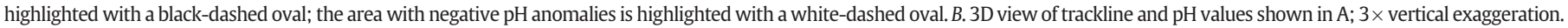
C. Profiles of $\mathrm{pH}$, turbidity, and dE/dt (time derivative of ORP) from MSN007-D and three CTD casts to show the depth range of the anomalies and correlations between variables.

A
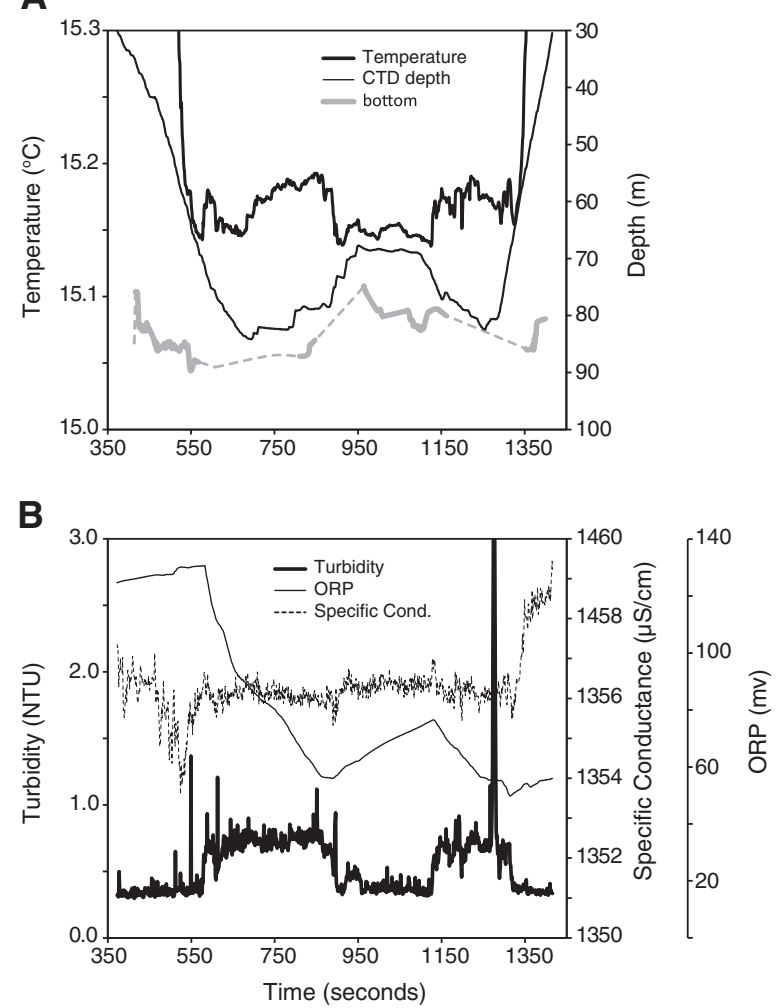

Fig. 5. A. CTD depth, bottom depth, and temperature for CTD-19 (location shown in Fig. 4A and Fig. 3B). B. Near-bottom turbidity, ORP, and specific conductance for CTD-19.
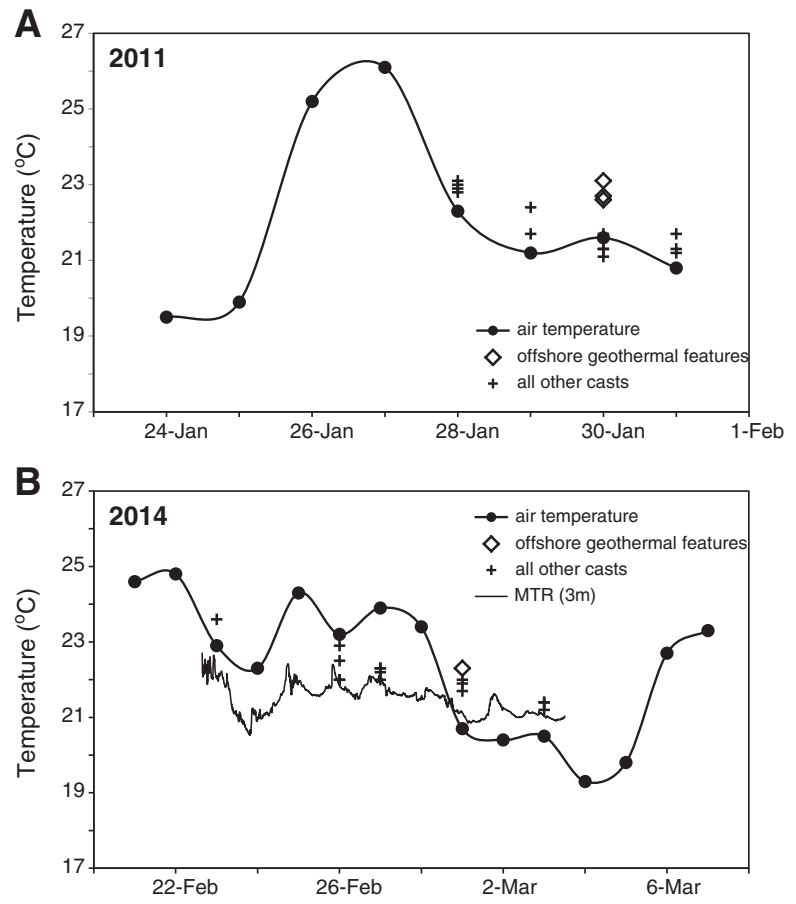

Fig. 6. A. Daily maximum air temperature (•; NIWA, CliFlo database, Rotorua Aero AWS, station no. 1770) compared to CTD surface temperatures for stations offshore the Steaming Cliffs, geyser, and boiling springs $(\diamond)$, and all other casts $(+)$ during the 2011 survey. B. Daily maximum air temperature (๑; NIWA, CliFlo database, Rotorua Aero AWS, station no. 1770) compared to the moored temperature sensor at $3 \mathrm{~m}$ (MTR), CTD surface temperatures for stations offshore the Steaming Cliffs, geyser, and boiling springs $(\diamond)$, and all other casts $(+)$ during the 2014 survey. 
A

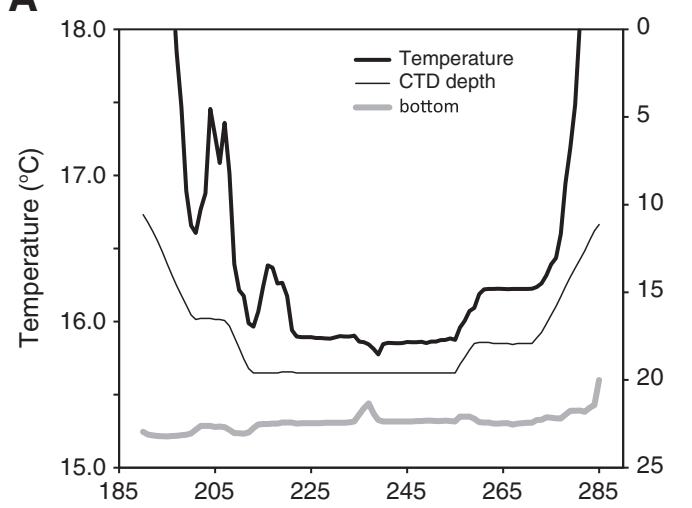

B

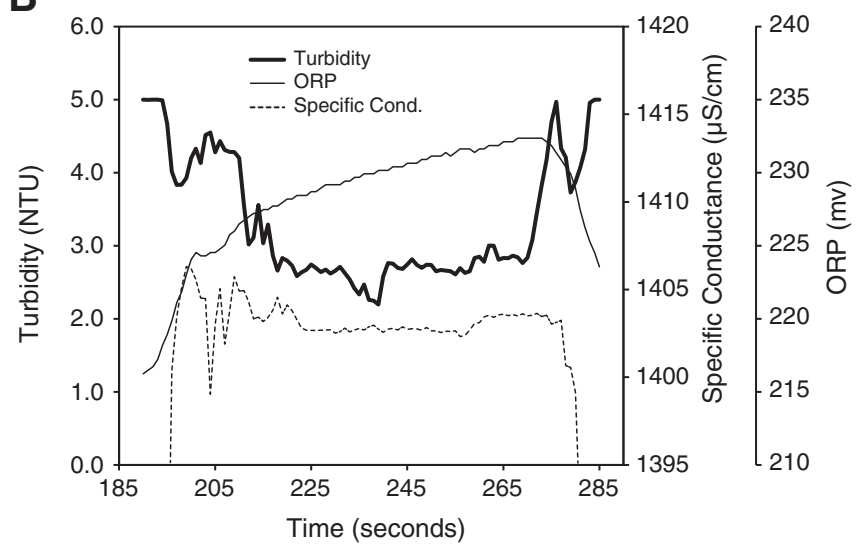

Fig. 7. A. CTD depth, bottom depth, and temperature for CTD-11 offshore the "Angel Wing" boiling spring (location shown in Fig. 3B). B. Near-bottom turbidity, ORP, and specific conductance for CTD-11.

There was a significant turbidity layer $(\Delta \mathrm{NTU}>0.5)$ below $\sim 70 \mathrm{~m}$ during CTD casts located adjacent to the base of the cliff (Fig. 4B). A strong ORP signal ( $\triangle \mathrm{E}=-74 \mathrm{mv}$ ) and temperature increase of up to $0.052{ }^{\circ} \mathrm{C}$ was associated with this particle layer (Fig. 5).

There was a slight turbidity anomaly $(\triangle \mathrm{NTU}=0.04)$ at $60 \mathrm{~m}$ water depth during one cast (CTD-25) located at the southern tip of the ridge. A slight ORP increase was seen at this depth in all casts in this area (Fig. 4B).

\subsection{Adjacent to western shoreline subaerial geothermal features}

CTD casts done 150-200 m offshore the geothermal features on the western shoreline of Lake Rotomahana show that the boiling springs, "Steaming Cliffs," and geysers impact the surface waters of the lake (see Stucker et al., 2016). Surface temperatures generally vary with air temperature, and during the time of both our 2011 and 2014 surveys decreased from $23{ }^{\circ} \mathrm{C}$ to $21^{\circ} \mathrm{C}$ (Fig. 6). Compared to the average surface temperature elsewhere in the lake for the day each of these casts were completed, surface temperatures in the areas of the western shoreline active features were warmer by $1.2-1.7^{\circ} \mathrm{C}$ (Fig. 6). Warmer temperatures were limited to the uppermost $1-3 \mathrm{~m}$.

Warm water is venting into Lake Rotomahana at depths of $20-30 \mathrm{~m}$ in the embayments near the "Angel Wing" boiling springs and the geyser (Figs. 7 and 8; see Stucker et al., 2016), areas where numerous gas plumes were also rising from the lake bed (de Ronde et al., 2016). Temperature anomalies of $0.5-1.2^{\circ} \mathrm{C}$ were seen $3-5 \mathrm{~m}$ above bottom (water depth $=16-20 \mathrm{~m}$ ) along with an increase in turbidity $(\Delta \mathrm{NTU}=1.7)$ and decrease in specific conductance near the Angel Wing spring. The temperature was warmer by $0.1{ }^{\circ} \mathrm{C}$ within $1-2 \mathrm{~m}$ of the lake bed (water depth $=27-30 \mathrm{~m}$ ) offshore the geyser and was

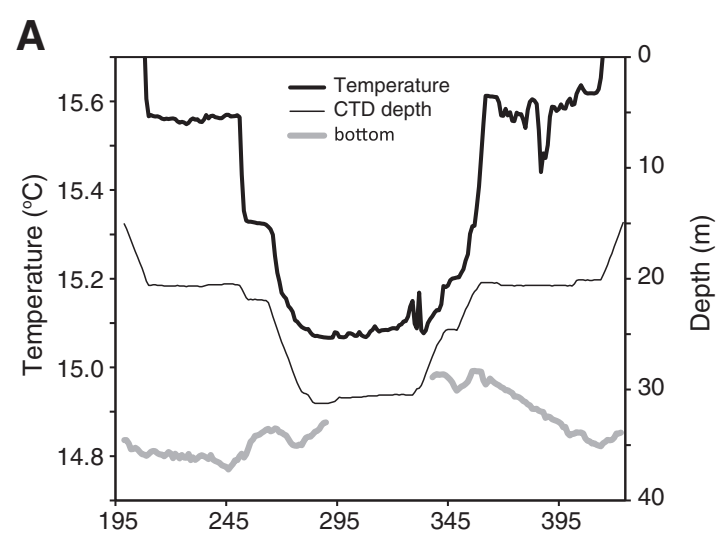

B

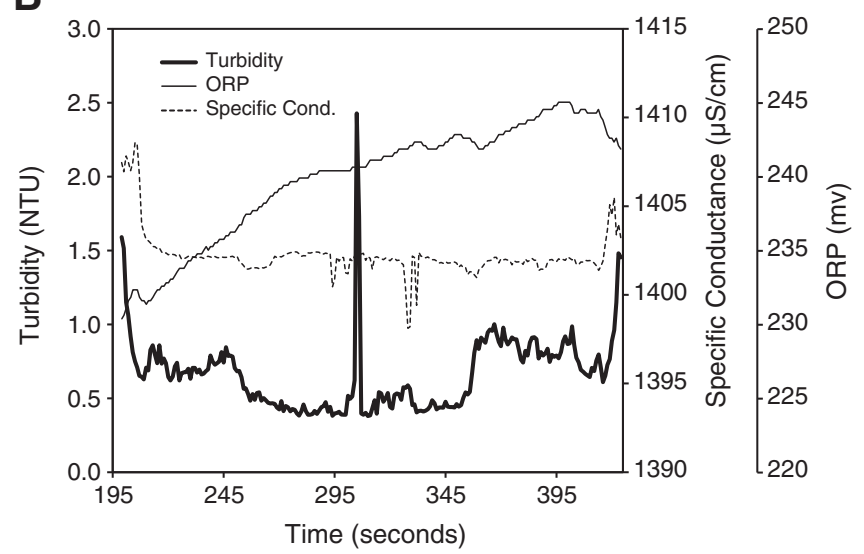

Fig. 8. A. CTD depth, bottom depth and temperature for CTD-10 offshore near the geyser (location shown in Fig. 3B). B. Near-bottom turbidity, ORP, and specific conductance for CTD-10.

associated with a decrease in specific conductance and a very slight ( $1 \mathrm{mv}$ ) increase in ORP. Occasional large particles (e.g., bubbles) can affect the optical backscatter sensor, and the large spike in turbidity (Fig. 8B) is likely due to the large amount of bubbles observed on the echosounder during the cast.

\subsection{North lakeshore}

There is an active hydrothermal discharge zone along the north lakeshore between the historic Pink and White Terrace sites. Temperature, ORP, and turbidity anomalies $\left(\Delta \mathrm{T}=4.7{ }^{\circ} \mathrm{C} ; \Delta \mathrm{NTU}=2.5\right.$; $\Delta \mathrm{E}=-27 \mathrm{mv}$ ) were located at $15-30 \mathrm{~m}$ water depth (Fig. 9). pH was also elevated $(+0.14 \mathrm{pH}$ units) within this depth range. A negative $\mathrm{pH}$ anomaly $(-0.08 \mathrm{pH}$ units) was seen further downslope at a depth of 53-55 m.

\subsection{Patiti hydrothermal system}

Warmer temperatures $\left(\Delta \mathrm{T}=\sim 0.05^{\circ} \mathrm{C}\right)$, lower $\mathrm{pH}(-0.08 \mathrm{pH}$ units, not shown), and bubble plumes characterize venting across a broad area along the southern margin of the 1886 Tarawera eruption rift west of Patiti Island (Fig. 10A), now named the Patiti hydrothermal system (de Ronde et al., 2016). The temperature sensor (MTR) mooring was located at the western end of this area and several CTD profiles were completed to monitor temporal changes at this site during our survey. A prominent turbidity layer $(\triangle \mathrm{NTU}=0.5)$ was present between 50 and $80 \mathrm{~m}$ for all casts, with an ORP signal $(\Delta \mathrm{E}=-25 \mathrm{mv})$ correlated with this layer for only the first pass through it. The CTD was moved from one position to another while the CTD was held at a depth of $77 \mathrm{~m}$ (7-10 $\mathrm{m}$ above the bottom) during cast CTD-15 (CTD-15a to CTD-15b; 

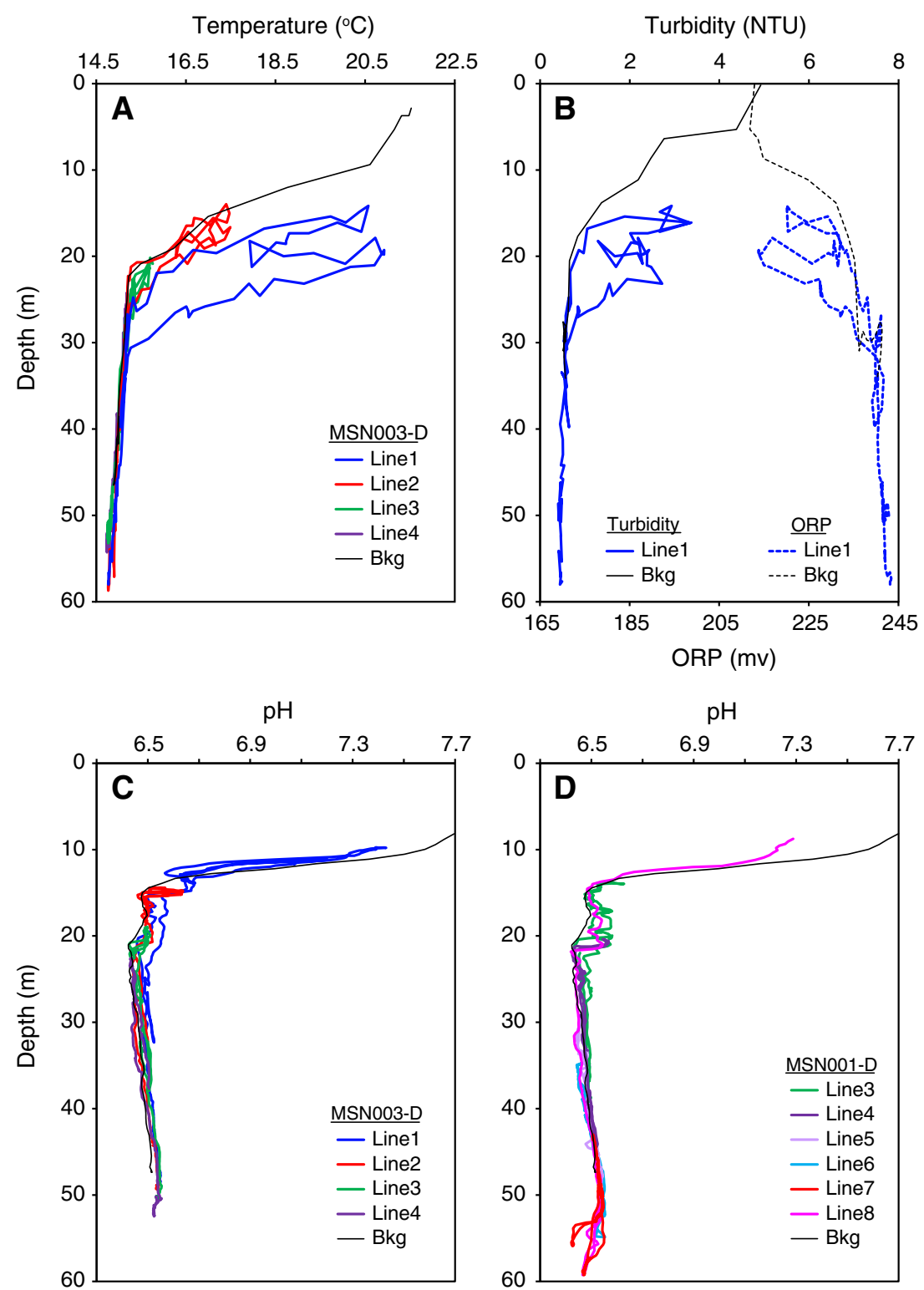

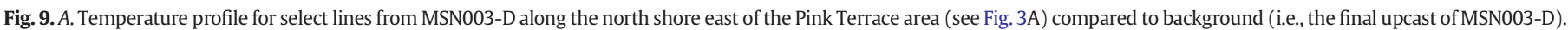

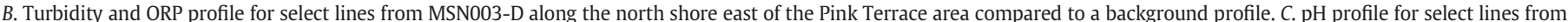

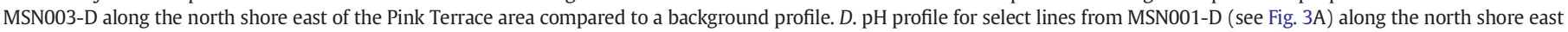
of the Pink Terrace area compared to the background profile. Note the increased pH from 15 to $22 \mathrm{~m}$ depth and the deeper anomaly at $55 \mathrm{~m}$ with a decrease in pH.

see Fig. 3B). Two distinct temperature anomalies $(\Delta \mathrm{T}=0.09$ and $0.13^{\circ} \mathrm{C}$ ) were encountered along this line (Fig. 11). ORP decreases accompanied each of these temperature anomalies $(\Delta \mathrm{E}=-28$ and $-47 \mathrm{mv}$, respectively). The magnitude of the temperature and ORP anomalies this high above the lake bed, and the limited horizontal extent, suggest the CTD intercepted rising (buoyant) hot fluids relatively close to their source.

Fig. 12 shows warmer temperature $\left(\Delta \mathrm{T}=0.06{ }^{\circ} \mathrm{C}\right)$ and decreasing $\operatorname{ORP}(\Delta \mathrm{E}=-46 \mathrm{mv})$ at a depth of $92-93 \mathrm{~m}$, within $1 \mathrm{~m}$ of the lake bottom, during CTD cast CTD-26, also located near the MTR mooring. This is the only instance encountered during our surveys where specific conductance increased in association with temperature and ORP anomalies.

\subsection{East basin}

Lake Rotomahana east of Patiti Island is shallower (max depth $\sim 75 \mathrm{~m}$ ) with cooler water temperatures in the hypolimnion and significantly lower heat flux than the deeper portions of the main basin north and west of Patiti Island (Whiteford and Bibby, 1995; Tivey et al., 2016). Our survey identified a hydrothermal discharge zone northeast of Patiti Island (Fig. 13) with decreased $\mathrm{pH}(-0.17 \mathrm{pH}$ units), increased ORP $(\Delta \mathrm{E}=+4 \mathrm{mv})$, and near-bottom (altitude $\sim 1-2 \mathrm{~m}$ ) temperature anomalies up to $\sim 0.25{ }^{\circ} \mathrm{C}$ at water depths of $42-46 \mathrm{~m}$ and $62 \mathrm{~m}$ at stations CTD-04 and CTD-30, respectively (Figs. 14 and 15). This area is along a steep ridge near a maar crater (named Smith crater, de Ronde et al., 2016) and is overlying the margin of an inferred basalt dike (Caratori Tontini et al., 2016).

The $\mathrm{pH}$ of deep water in the east part of the lake is about $0.12 \mathrm{pH}$ units higher than the western portion (main basin) of the lake (Fig. 13), and along with generally lower temperatures (not shown) suggest limited mixing of the hypolimnion along the SW-NE axis of the lake.

\subsection{Star Hill Crater}

Star Hill Crater is a steep-sided explosion crater formed during the 1886 eruption. It is located on the north shore of Lake Rotomahana 


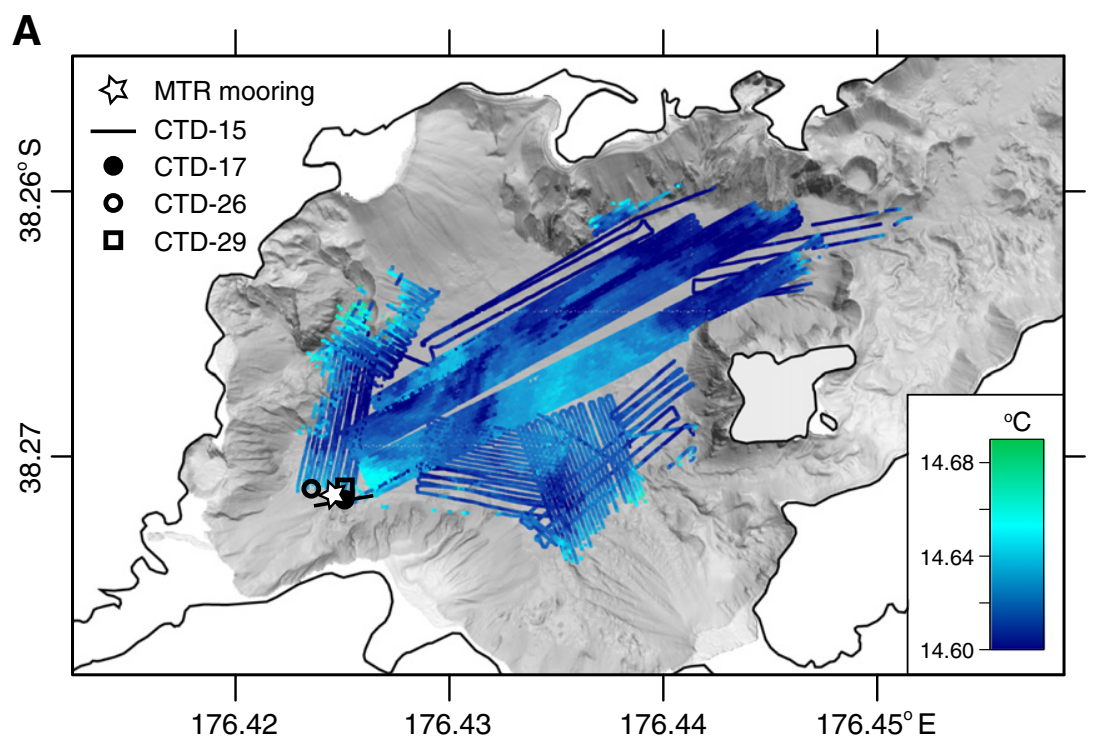

B Turbidity (NTU)

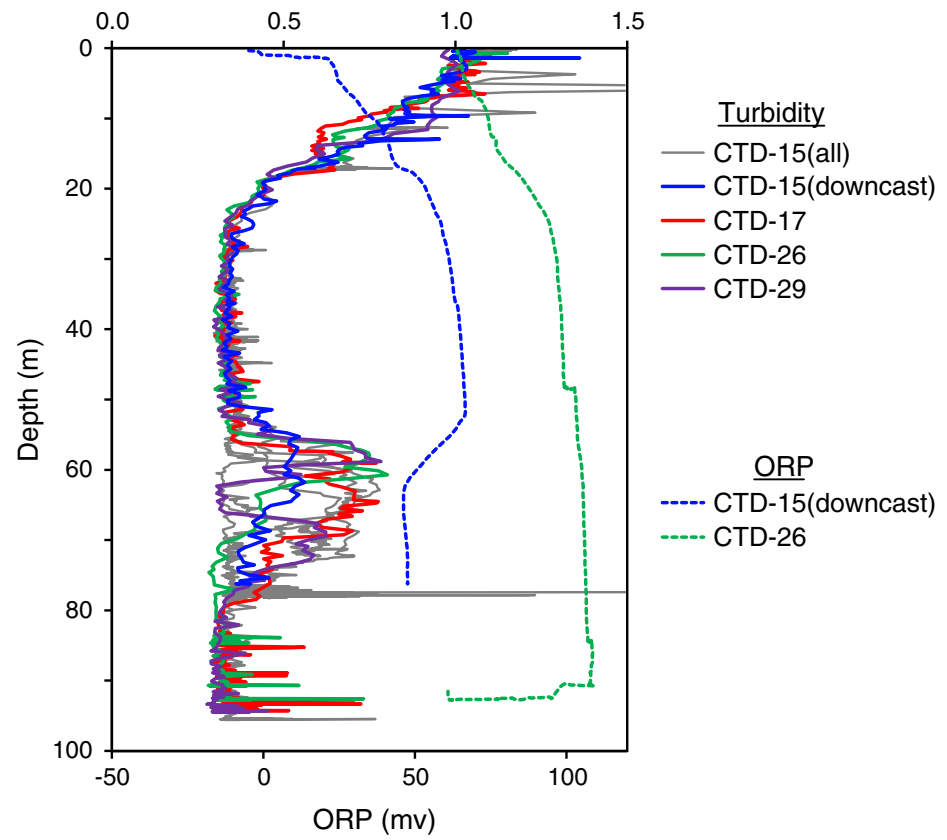

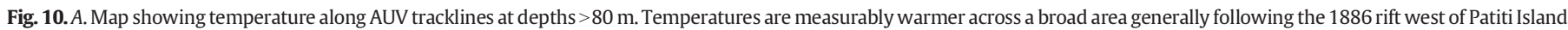

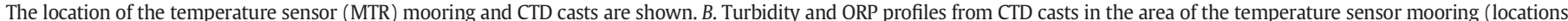
shown in Fig. 10A and Fig. 3B).

north of Patiti Island (Fig. 3B). The crater has a bottom depth of $25 \mathrm{~m}$ and is separated from the main body of Lake Rotomahana by a sill with a maximum depth of 8-10 m (see de Ronde et al., 2016; Keam, 2016). Two profiles were completed within Star Hill Crater (CTD-12 in 2011, and a camera lowering with a MAPR in 2014). During both profiles, the water below the sill depth had increased turbidity and the ORP dropped sharply to negative values ( $\Delta \mathrm{E}=-200$ to $-300 \mathrm{mv}$ ). The temperature below $10 \mathrm{~m}$ water depth was cooler than water at similar depths in the main body of the lake by $0.75{ }^{\circ} \mathrm{C}$ in 2011 and $\sim 1.25{ }^{\circ} \mathrm{C}$ in 2014. The cooler temperature and strongly negative ORP values indicate this crater is not currently hydrothermally active, but that circulation with the rest of the lake is impeded by the sill and conditions are anoxic below sill depth during summer.

\subsection{Event response?}

The seasonal warming rate of Lake Rotomahana hypolimnion during the period of stratification has been remarkably constant for the past two decades. The warming rates observed during our 2014 survey and the first several days of our 2011 survey were consistent with the historical warming rate of $0.010{ }^{\circ} \mathrm{C} /$ day $\pm 0.001{ }^{\circ} \mathrm{C}$. However, there was a sudden and much greater increase in hypolimnion temperature on the fifth day into our 2011 survey (29 January). This jump in temperature was observed in both MAPR instruments on the AUVs and was most pronounced in water depth $>60 \mathrm{~m}$ in the main basin (i.e., not observed east of Patiti Island). Fig. 16 shows the temperature profiles below $60 \mathrm{~m}$ for all AUV descents and ascents through the full water column. Due to a 
A

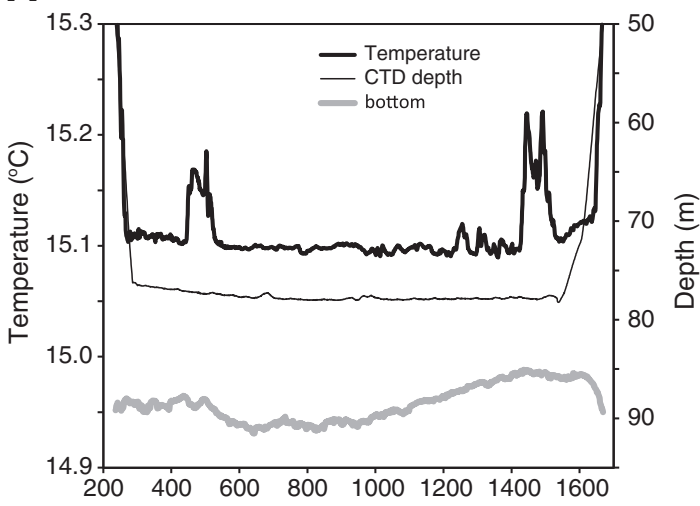

B

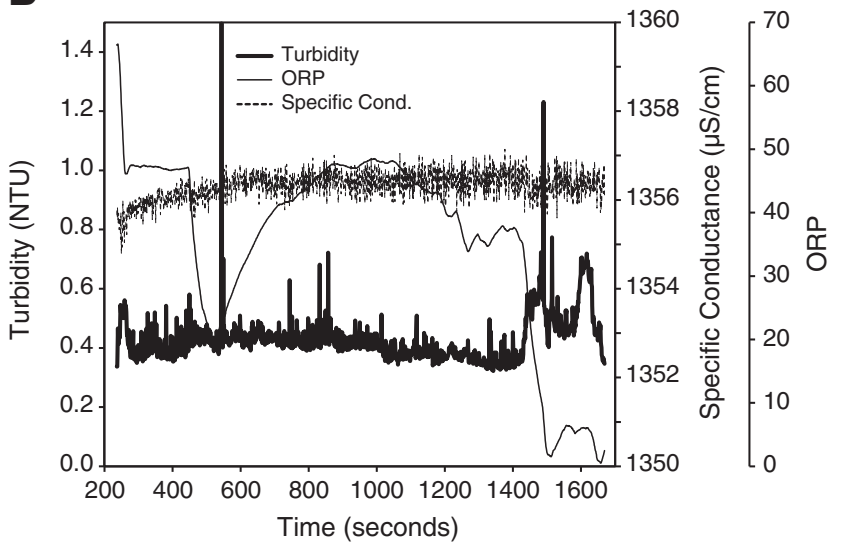

Fig. 11. A. CTD depth, bottom depth, and temperature for CTD-15 (while transiting between 15a and 15b; location shown in Figs. 10A and 3B). B. Near-bottom turbidity, ORP, and specific conductance for CTD-15.

slight offset between individual MAPRs $\left(\sim 0.08^{\circ} \mathrm{C}\right.$, see Fig. 16$)$, the temperature increase was analyzed separately for each instrument and is summarized in Table 2. The average temperature offset between the predicted temperature for water at $80 \mathrm{~m}$ based on the warming trend in the early part of the survey vs the measured temperatures after 28 January 2011 was $+0.025^{\circ} \mathrm{C}$ (Table 2 ).

The energy required for this temperature increase can be estimated following Tivey et al. (2016):

$E=\rho V C_{p} \frac{d T}{d T}$

where $V$ is volume of water below $60 \mathrm{~m}$ for the main basin only $\left(0.128 \mathrm{~km}^{3}\right)$, and assuming standard values for fresh water density $\left(\rho=999.1 \mathrm{~kg} / \mathrm{m}^{3}\right.$ at $\left.15^{\circ} \mathrm{C}\right)$ and specific heat capacity $\left(C_{p}=\right.$ $4186 \mathrm{~J} / \mathrm{kg} \mathrm{K}$ ). This temperature increase required the sudden addition of $1.3 \times 10^{13} \mathrm{~J}(\sim 150 \mathrm{MW}$ over the course of one day), which is approximately equal to the "steady-state" total energy input to the entire lake calculated by Tivey et al. (2016).

\section{Discussion}

Our survey has discovered five active hydrothermal discharge zones in Lake Rotomahana, including the area of the historic Pink Terraces where hot springs that pre-dated the 1886 Tarawera eruption appear to have survived the eruption and continue to be active today (see Keam, 2016; de Ronde et al., 2016; Caratori Tontini et al., 2016). By contrast, active venting in the east basin (northeast of Patiti Island), the Patiti hydrothermal system (along the southern margin of the
A
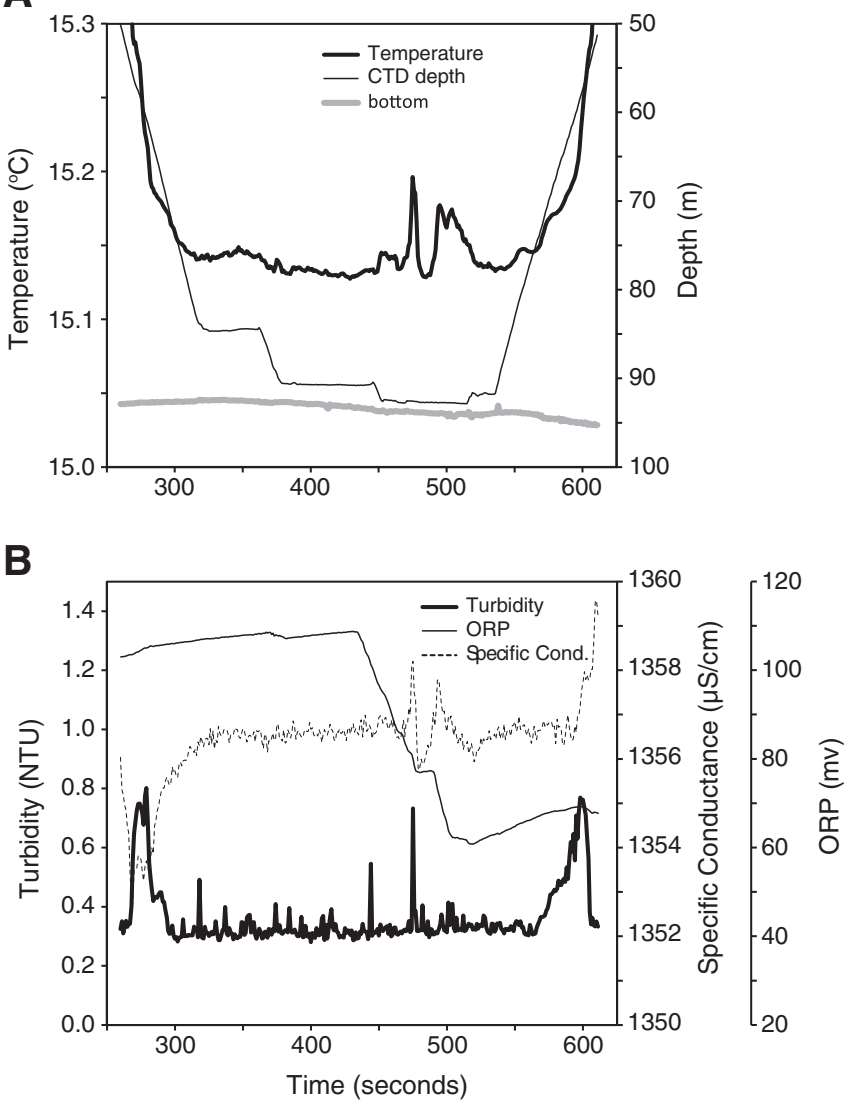

Fig. 12. A. CTD depth, bottom depth, and temperature for CTD-26 (location shown in Figs. $10 \mathrm{~A}$ and $3 \mathrm{~B}$ ). $B$. Near-bottom turbidity, ORP, and specific conductance for CTD-26.

1886 rift zone west of Patiti Island), along the northern lakeshore, and adjacent to the subaerial features on the western shoreline appears to have been initiated by the eruption, along with the activity in Waimangu Valley (see Keam, 2016; de Ronde et al., 2016). All areas of active venting, except for the east basin site, are correlated with areas of the highest conductive heat flux mapped by Tivey et al. (2016).

Geophysical studies indicate a deep geothermal reservoir under Waimangu Valley that extends eastward to the western portion of Lake Rotomahana (see de Ronde et al., 2016; Caratori Tontini et al., 2016; Heise et al., 2016; Bannister et al., 2016; Stucker et al., 2016). The strongly demagnetized anomaly under the west end of the lake suggests significant subsurface hydrothermal alteration must have pre-dated the 1886 Tarawera eruption despite the absence of surface vents (see Caratori Tontini et al., 2016; Keam, 2016). The Pink Terrace area, western shoreline and northern shoreline hydrothermal discharge zones are correlated with this magnetic anomaly, as is the westernmost end of the Patiti hydrothermal system where the MTR mooring was located. However, the remainder of the Patiti hydrothermal discharge zone has no demagnetization anomaly associated with it, and there is no history of geothermal activity in this area prior to the 1886 eruption. The water column data show that this new Patiti hydrothermal system has similar characteristics (i.e., the magnitude of temperature, $\mathrm{pH}$, and turbidity anomalies) as the Pink Terrace site, implying similar fluid types and venting intensity, which supports the interpretation of Caratori Tontini et al. (2016) that the reason demagnetization through most of this zone is absent is because it has not been active long enough to alter the magnetic signature of the host rocks.

Hydrothermal discharge in the basin east of Patiti Island is located $\sim 2.5 \mathrm{~km}$ east of the historic Pink Terraces site in the approximate 


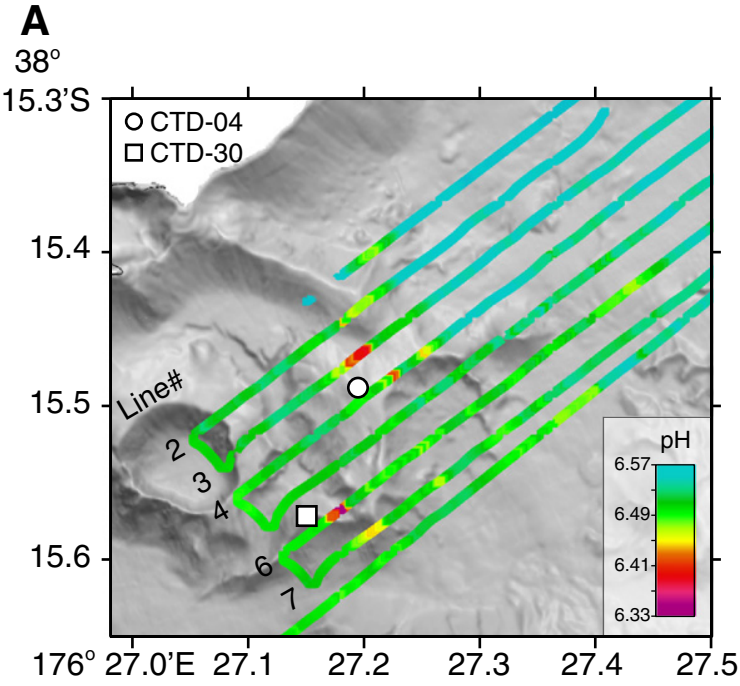

B

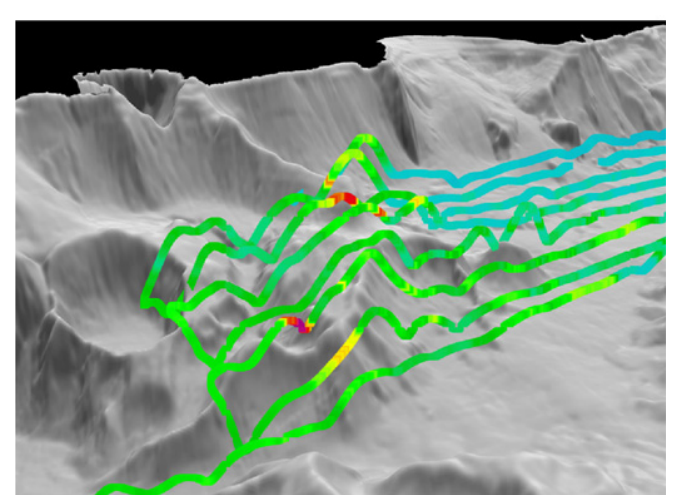

\section{C}

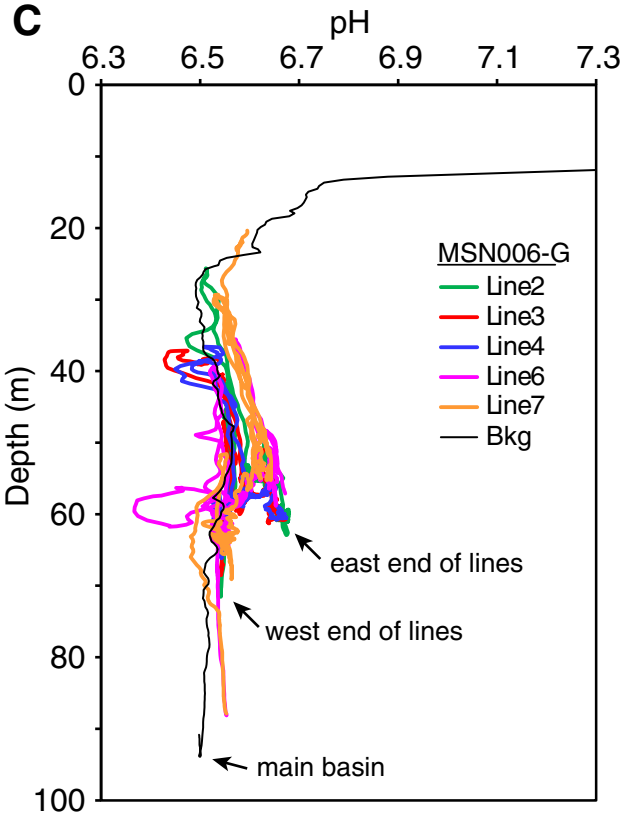

Fig. 13. A. Map showing pH values along the trackline of AUV mission MSNO06-G in the east basin (location shown in Fig. 3A). B. 3D view of trackline and $\mathrm{pH}$ values shown in $\mathrm{A}$; $3 \times$ vertical exaggeration. $C$. Profiles of $\mathrm{pH}$ for select lines from MSN006-G showing the depths and magnitude of $\mathrm{pH}$ anomalies. The $\mathrm{pH}$ distribution with depth bifurcates below $\sim 60 \mathrm{~m}$. The higher $\mathrm{pH}$ values occur throughout the east basin, the lower $\mathrm{pH}$ values occur at the west side which sampled deep water from the main basin. location of the eastern shore of old "cold lake" Rotomakariri. This location is also coincident with a line of craters formed during the 1886 eruption (see de Ronde et al., 2016), is near the boundary of an inferred basalt dike (see Caratori Tontini et al., 2016), and lies just to the east of an area of slightly elevated heat flux (see Tivey et al., 2016); all indicative of dramatic changes to local subsurface permeability caused by the eruption resulting in new conduits for deep fluids and gas to escape. It is worth noting that the northern shoreline and western shoreline vent sites also occur near the boundaries of basalt dikes identified by Caratori Tontini et al. (2016) as possibly emplaced during the 1886 eruption.

The characteristics of active venting on the lake floor are variable. Warm water was found at each of these five hydrothermal discharge zones, however, there were differences between sites with respect to $\mathrm{pH}$, turbidity, ORP, and specific conductance anomalies, sometimes within short distances. For example, in the Pink Terrace area, $\mathrm{pH}$ anomalies with both increased and decreased values relative to the local background were located about $200 \mathrm{~m}$ apart indicating fluid pathways and subsurface conditions are variable across short distances. Discharge zones where increased turbidity correlates strongly with negative ORP anomalies suggest more reduced fluids that may contain higher concentrations of sulfides and dissolved metals and were seen at the Pink Terrace, northern shoreline, and Patiti hydrothermal system (near the MTR mooring) sites. The northern shoreline site is located, in part, in shallow water where biological productivity may also contribute to increased turbidity if geothermal inputs enhance primary productivity in the photic zone through the addition of otherwise limiting micronutrients, or stimulate the growth of chemoautosynthetic microbes in the water column (Cuhel et al., 2002). The eastern basin site is characterized by low $\mathrm{pH}$ and slightly elevated ORP anomalies, a pattern consistent with high concentrations of dissolved $\mathrm{CO}_{2}$ dominating these fluids (S. L. Walker, unpublished data). This variability mirrors the diversity seen among Waimangu Valley geothermal features and is consistent with a variety of subsurface conditions and pathways for fluids leading to vents on the lake floor, similar to what has been inferred for Waimangu Valley and the subaerial Rotomahana shoreline hot springs (Sheppard, 1986; Stucker et al., 2016).

The geothermal fluids of the Waimangu-Rotomahana hydrothermal system are enriched in dissolved solids, both ionic (e.g., sodium chloride, which will increase specific conductance) and non-ionic (e.g., silica species, which will not affect specific conductance; McManus and Collier, 1992), and Lake Rotomahana has higher specific conductance than other Rotorua area lakes due to the geothermal fluid input (i.e., 11001400 for Lake Rotomahana compared to $400-500$ for Lake Tarawera; LERNZ database). However, specific conductance was of limited value as a tracer for active hydrothermal venting during our study with only one instance (CTD-26; Fig. 12) where increased temperature was correlated with increased specific conductance.

The sudden increase in hypolimnic temperature during our 2011 survey required a pulse of $1.3 \times 10^{13} \mathrm{~J}$ of added energy to the lake (or an extra $\sim 150$ MW during a single day). According to Bannister et al. 2016, a seismic swarm of 15 events over a span of 4 hours $\left(\sim M_{L} 2\right)$ occurred on January $16-17$, just 11 days prior to this sudden temperature increase. These events were focused near the western shoreline and Pink Terrace discharge sites (see Bannister et al., 2016) and probably modified the permeability along the inferred subsurface fault to allow a sudden release of heat (i.e., hot fluids) to migrate into the lake. The temperature of the deep geothermal source fluids is estimated to be 200-230 ${ }^{\circ} \mathrm{C}$ (Stucker et al., 2016). Rearranging Eq. (1), the volume of $200{ }^{\circ} \mathrm{C}$ water required to carry this much energy to the lake is $\sim 15.5 \times 10^{3} \mathrm{~m}^{3}$, about $0.01 \%$ of the affected lake volume (i.e., below $60 \mathrm{~m}$ and excluding the area east of Patiti Island). Similar short-lived increases in vent temperature following seismic swarms and in response to volcanic events have been observed at mid-ocean ridge hydrothermal systems (Baker et al., 1989; Sohn et al., 1999; Johnson et al., 2000). 
A

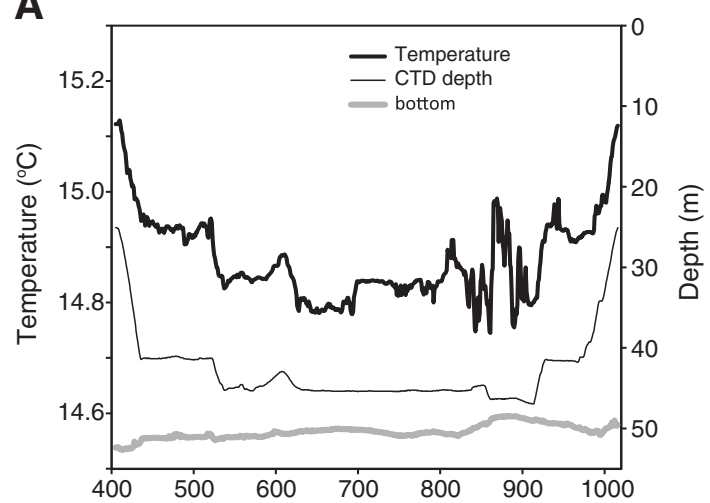

B

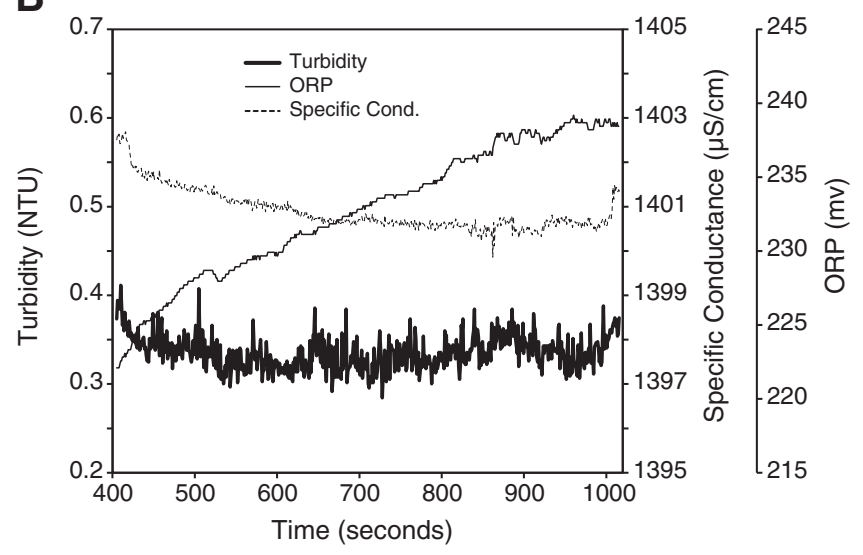

Fig. 14. A. CTD depth, bottom depth, and temperature for CTD-04 (location shown in Figs. $13 \mathrm{~A}$ and $3 \mathrm{~B}$ ). B. Near-bottom turbidity, ORP, and specific conductance for CTD-04.

At least one other instance of a sudden increase in hypolimnion temperature can be identified in the historical temperature profile data (LERNZ data base) for Lake Rotomahana (see Table 1): temperature at $66 \mathrm{~m}$ increased by $0.5{ }^{\circ} \mathrm{C}$ between 12 December 1996 and 07 January 1997 (26 days) for an average warming rate during this period of $0.019{ }^{\circ} \mathrm{C} /$ day, double the historic average seasonal warming rate. A burst of seismic activity occurred just 3 days before the January profile with 50 events in less than 6.5 hours (Bannister et al., 2016). The warming rate from September to December 1996, determined from 3 profiles taken in September, October, and December, was $0.0094^{\circ} \mathrm{C} / \mathrm{day}$. If we assume this warming rate was constant up to the 04 January event, the actual temperature increase following the earthquake swarm was $0.28{ }^{\circ} \mathrm{C}$, which is $\sim 10$ times higher than the 2011 event.

Ongoing seismic activity will contribute to the maintenance and/or alteration of subsurface permeability around the common deep geothermal fluid source for Waimangu-Rotomahana geothermal features. Because the seismic activity tends to occur in bursts along localized sections of the underlying fault (Bannister et al., 2016), the impact on Lake Rotomahana will likely be intermittent pulses of increased heat, fluid, and gas.

\section{Conclusions}

Five areas of active sublacustrine hydrothermal venting occur within Lake Rotomahana. Four of these are located in the western part of the lake and are correlated with areas of the highest conductive heat flux as mapped by Tivey et al. (2016) including the Pink Terrace area; adjacent to the subaerial geothermal features along the western shoreline; along the northern shoreline; and in a broad area along the southern margin of the 1886 eruption rift (Patiti hydrothermal system). The
A

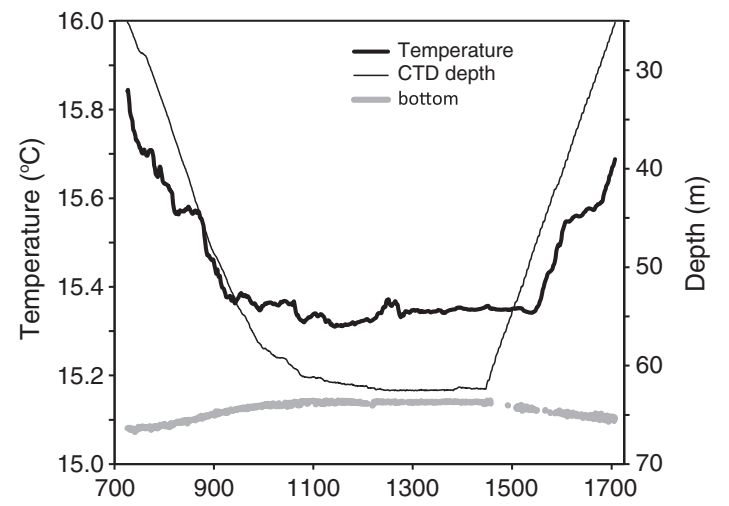

B

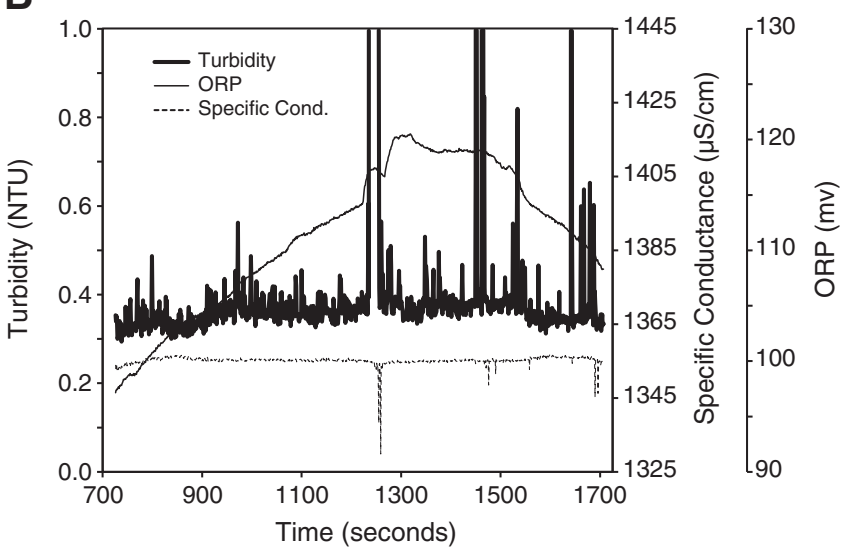

Fig. 15. A. CTD depth, bottom depth, and temperature for CTD-30 (location shown in Figs. 13A and 3B). B. Near-bottom turbidity, ORP, and specific conductance for CTD-30.

Pink Terrace site was active prior to the 1886 Tarawera eruption. The four new (post-1886) areas of venting include the northern and western shoreline sites, the Patiti hydrothermal system and the east basin vent site; each of these zones occur in the vicinity of basalt dikes that were likely emplaced during the 1886 eruption (Caratori Tontini et al., 2016), disturbing an apparently long-lived geothermal reservoir and opening new pathways to provide fluids to an extended region of surface venting including Waimangu Valley and the discharge zones beneath Lake Rotomahana.

The seasonal period of water column stratification in Lake Rotomahana (September through May) allows heat to accumulate below the thermocline at a rate significantly faster than nearby Lake Tarawera, which has only limited geothermal input. The average seasonal warming rate has been $0.010{ }^{\circ} \mathrm{C} /$ day $\pm 0.001{ }^{\circ} \mathrm{C}$ for the past two decades. Periodically, as was seen in the January 1997 LERNZ data and during our 2011 survey, sudden increases in temperature appear to be the result of seismic activity along faults near the deep geothermal fluid reservoir that alter the subsurface permeability and provide a mechanism for pulses of excess heat to reach the lake.

\section{Acknowledgements}

We thank Dirk Immenga, Bradley Scott, Amy Kukulya, Robin Littlefield, and Vicki Ferrini for excellent boat handling and AUV operations support. We thank the Te Arawa Lakes Trust Board for permission to complete this work, and the Waimangu Volcanic Valley management and staff for allowing access and providing logistical support. We also thank reviewers Edward Baker and Agnes Mazot for their helpful comments to improve the manuscript. Funding was provided by GNS Strategic Development Fund. This is PMEL contribution 4294. I would 

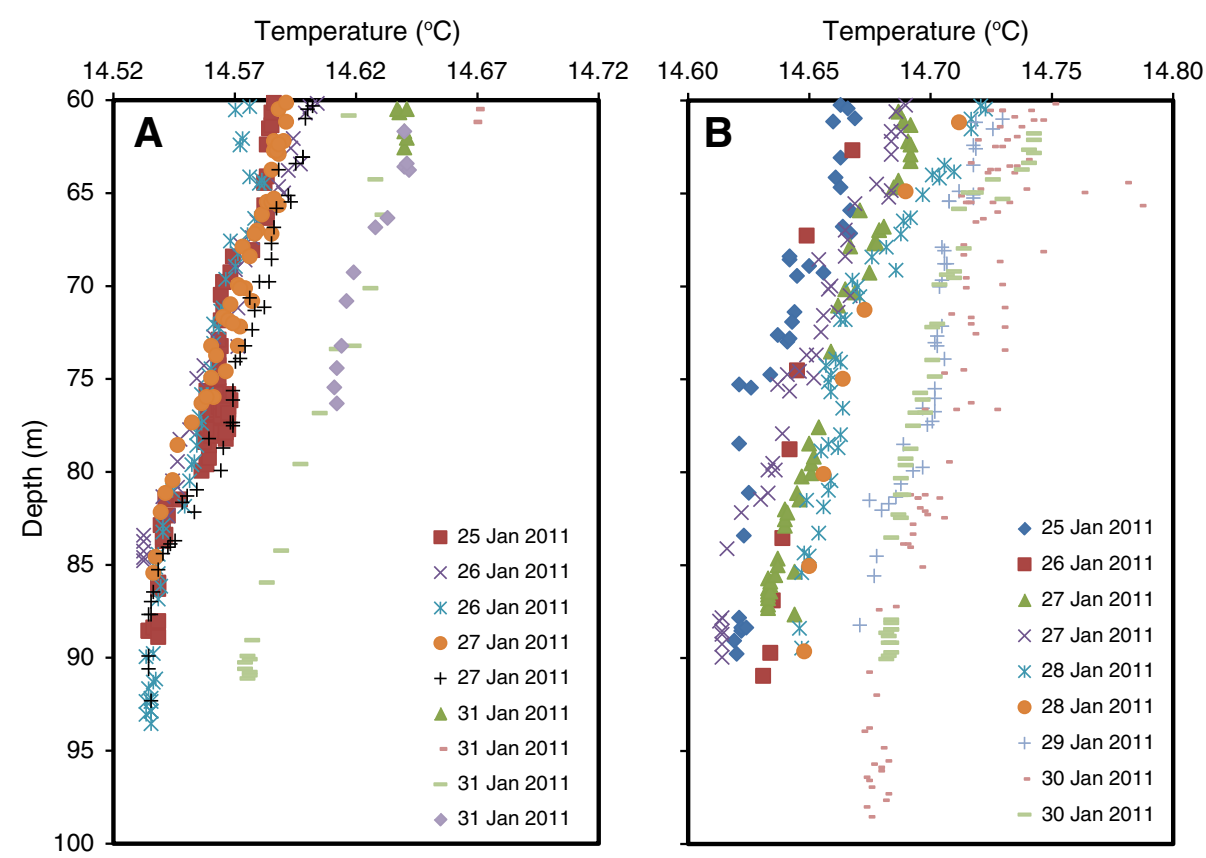

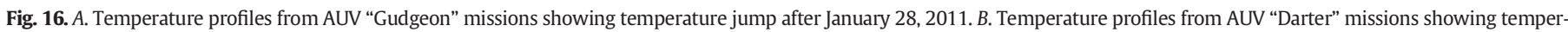

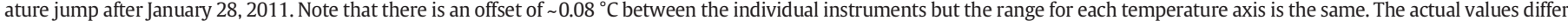

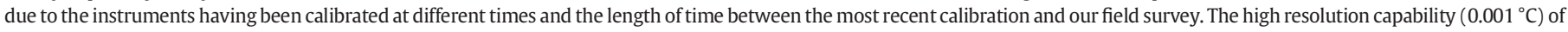
the sensors is not affected.

Table 2

Predicted and measured temperature $\left({ }^{\circ} \mathrm{C}\right)$ at $80 \mathrm{~m}$ after 28 January 2011.

\begin{tabular}{lllll}
\hline Vehicle & Date & $\begin{array}{l}\text { Predicted } \\
\text { temperature }\end{array}$ & $\begin{array}{l}\text { Measured } \\
\text { temperature }\end{array}$ & $\begin{array}{l}\Delta \mathrm{T} \\
\left({ }^{\circ} \mathrm{C}\right)\end{array}$ \\
\hline "Darter" & 29-Jan-2011 & 14.667 & 14.692 & 0.025 \\
& 30-Jan-2011 & 14.675 & 14.694 & 0.019 \\
"Gudgeon" & 31-Jan-2011 & 14.560 & 14.593 & 0.033 \\
& & & average $\Delta \mathrm{T}=$ & 0.026 \\
\hline
\end{tabular}

like to dedicate this paper to my brother Steven Lawrence Walker (1960-2014) who was always very supportive and interested in our work.

\section{References}

American Public Health Association, 1985. Standard Methods for the Examination of Water and Wastewater. 16th ed. American Public Health Association, A.W.W.A, and W.P.C.F. Joint Publication, Washington, DC (1,268 pp.)

Baker, E.T., Lavelle, J.W., Feely, R.A., Massoth, G.J., Walker, S.L., Lupton, J.E., 1989. Episodic venting of hydrothermal fluids from the Juan de Fuca Ridge. J. Geophys. Res. 94 (B7), 9237-9250. http://dx.doi.org/10.1029/JB094iB07p09237.

Baker, E.T., Haymon, R.M., Resing, J.A., White, S.M., Walker, S.L., Macdonald, K.C. Nakamura, K., 2008. High-resolution surveys along the hot spot-affected Galápagos Spreading Center: 1. Distribution of hydrothermal activity. Geochem. Geophys. Geosyst. 9 (9). http://dx.doi.org/10.1029/2008GC002028 (Q09003).

Baker, E.T., Walker, S.L., Embley, R.W., de Ronde, C.E.J., 2012. High-resolution hydrothermal mapping of Brothers caldera, Kermadec arc. Econ. Geol. 107, 1583-1593. http://dx.doi.org/10.2113/econgeo.107.8.1583.

Bannister, S., Sherburn, S., Bourguignon, S., 2016. Earthquake swarm activity highlights a crustal fault associated with the Waimangu-Rotomahana-Mt Tarawera geothermal field, Taupo Volcanic Zone, New Zealand. J. Volcanol. Geotherm. Res. 314, 49-56.

Caratori Tontini, F., de Ronde, C.E.J., Scott, B., Soengkono, S., Stagpoole, V., Timm, C., Tivey, M., 2016. Interpretation of gravity and magnetic anomalies at Lake Rotomahana: geological and hydrothermal implications. J. Volcanol. Geotherm. Res. 314, 84-94.

Crane, K., Hecker, B., Golubev, V., 1991. Hydrothermal vents in Lake Baikal. Nature 350, 281

Cuhel, R.L., Aguilar, C., Anderson, P.D., Maki, J.S., Paddock, R.W., Remsen, C.C., Klump, J.V., Lovalvo, D., 2002. Underwater domains in Yellowstone Lake hydrothermal vent geochemistry and bacterial chemosynthesis. In: Anderson, R.J., Harmon, D. (Eds.), Yellowstone Lake: Hotbed of Chaos or Reservoir of Resilience? Proceedings of the 6th Biennial Scientific Conference on the Greater Yellowstone Ecosystem. Yellowstone Center for Resources and George Wright Society, Yellowstone National Park, WY, pp. 27-53. de Ronde, C.E.J., Baker, E.T., Massoth, G.J., Lupton, J.E., Wright, I.C., Feely, R.A., Greene, R.R. 2001. Intra-oceanic subduction-related hydrothermal venting, Kermadec volcanic arc, New Zealand. Earth Planet. Sci. Lett. 193 (3-4), 359-369. http://dx.doi.org/10. 1016/S0012-821X(01)00534-9.

de Ronde, C.E.J., Stoffers, P., Garbe-Schönberg, D., Christenson, B.W., Jones, B., Manconi, R. Browne, P.R.L., Hissmann, K., Botz, R., Davy, B.W., Schmitt, M., Battershill, C.N., 2002 Discovery of active hydrothermal venting in Lake Taupo, New Zealand. J. Volcanol. Geotherm. 115, 257-275.

de Ronde, C.E.J., Baker, E.T., Massoth, G.J., Lupton, J.E., Wright, I.C., Sparks, R.J., Bannister, S.C., Reyners, M.E., Walker, S.L., Greene, R.R., Ishibashi, J., Faure, K., Resing, J.A., Lebon, G.T., 2007. Submarine hydrothermal activity along the mid-Kermadec Arc, New Zealand: Large-scale effects on venting. Geochem. Geophys. Geosyst. 8 (7), Q07007. http://dx.doi.org/10.1029/2006GC001495.

de Ronde, C.E.J., et al., 2016. Reconstruction of the geology and structure of Lake Rotomahana and its hydrothermal systems from high-resolution multibeam mapping and seismic surveys: Effects of the 1886 Tarawera Rift eruption. J. Volcanol. Geotherm. Res. 314, 57-83.

Dymond, J., Collier, R.W., Watawood, M., 1989. Bacterial mats from Crater Lake, Oregon and their relationship to possible deep-lake hydrothermal venting. Nature 342, 673-675.

German, C.R., Yoerger, D.R., Jakuba, M. Shank, T.M., Langmuir, C.H., Nakamura, K. 2008 Hydrothermal exploration with the Autonomous Benthic Explorer. Deep-Sea Res. I 55, 203-219. http://dx.doi.org/10.1016/j.dsr.2007.11.004.

Heise, W., Caldwell, T.G., Bertrand, E.A., Hill, G.J., Bennie, S.L., Palmer, N.G., 2016. Imaging the deep source of the Rotorua and Waimangu geothermal fields, Taupo Volcanic Zone, New Zealand. J. Volcanol. Geotherm. Res. 314, 39-48.

Hutchinson, G.E., 1957. A Treatise on Limnology. Geography, Physics and Chemistry vol. 1. Wiley, New York.

Irwin, J., 1968. Observations of temperatures in some Rotorua Lakes. N.Z. J. Mar. Freshw. Res. 2, 591-605.

Johnson, H.P., Hutnak, M., Dziak, R.P., Fox, C.G., Urcuyo, I., Cowen, J.P., Nabelek, J., Fisher, C. 2000. Earthquake-induced changes in a hydrothermal system on the Juan de Fuca mid-ocean ridge. Nature 407, 174-177.

Jolly, Y.H., 1968. The comparative limnology of some New Zealand lakes. N.Z. J. Mar Freshw. Res. 2, 214-259.

Keam, R., 2016. The Tarawera eruption, Lake Rotomahana, and the origin of the Pink and White Terraces. J. Volcanol. Geotherm. Res. 314, 10-38.

Keywood, M., Rodgers, K.A., Nicholson, K., 1992. A catalog of thermal features in the Waimangu Valley, 1990. N. Z. Volcanol. Rec. 19, 29-51.

Mazot, A., Schwandner, F.M., Christenson, B., de Ronde, C.E.J., Inguaggiato, S., Scott, B., Graham, D., Britten, K., Keeman, J., Tan, K., 2014. CO2 discharge from the bottom of volcanic Lake Rotomahana, New Zealand. Geochem. Geophys. Geosyst. 15 (3), 577-588. http://dx.doi.org/10.1002/2013GC004945.

McManus, J., Collier, R.W., 1992. Physical properties of Crater Lake, Oregon: a method for determination of a conductivity- and temperature-dependent expression for salinity. Limnol. Oceanogr. 37 (1), 41-53.

Morgan, L.A., Shanks III, W.C., Lovalvo, D.A., Johnson, S.Y., Stephenson, W.J., Pierce, K.L., Harlan, S.S., Finn, C.A., Lee, G., Webring, M., Schulze, B., Dühn, J., Sweeney, R. Balistrieri, L., 2003. Exploration and discovery in Yellowstone Lake: results from 
high-resolution sonar imaging, seismic reflection profiling, and submersible studies. J. Volcanol. Geotherm. Res. 122, 221-242.

Nairn, I.A., 1989. Geology of Mount Tarawera, Geological Map of New Zealand, 1:50 000, Sheet V16 AC. New Zealand Geological Survey. DSIR, Lower Hutt, NZ.

Nakamura, K., Veirs, S., Sarason, C.P., McDuff, R.E., Stahr, F., Yoerger, D.R., Bradley, A.M., 2000. Electrochemical signals in rising buoyant plumes and tidally oscillating plumes at the Main Endeavour vent field, Juan de Fuca Ridge [abs]. EOS Trans. Am. Geophys. Union 81 (48) (Fall Meeting Supplement, Abstract OS521-05).

Remsen, C.C., Val Klump, J., Kaster, J., Paddock, R., Anderson, P., Maki, J.S., 1990. Hydrothermal springs and gas fumaroles in Yellowstone Lake, Yellowstone National Park Wyoming. Natl. Geogr. Res. 6 (4), 509-515.

Sheppard, D.S., 1986. Fluid chemistry of the Waimangu Geothermal System. Geothermics 15 (3), 309-328.

Simmons, S.F., Keywood, M., Scott, B.J., Keam, R.F., 1993. Irreversible change of the Rotomahana-Waimangu Hydrothermal System (New-Zealand) as a consequence of a volcanic-eruption. Geology 21 (7), 643-646.

Simmons, S.F., Stewart, M.K., Robinson, B.W., Glover, R.B., 1994. The chemical and isotopic compositions of thermal waters at Waimangu, New-Zealand. Geothermics 23 (5-6), 539-553.

Sohn, R.A., Hildebrand, J.A., Webb, S.C., 1999. A microearthquake survey of the hightemperature vent fields on the volcanically active East Pacific Rise $\left(9^{\circ} 50^{\prime} \mathrm{N}\right)$. J. Geophys. Res. 104 (B11), 23367-25377.

Stucker, V.K., de Ronde, C.E.J., Scott, B., Wilson, N., Walker, S.L., Plaber-Friedrich, B., Lupton, J.E., 2016. Subaerial and sublacustrine hydrothermal activity at Lake Rotomahana. $314,156-168$
Tiercelin, J.-J., Pflumio, C., Castrec, M., Boulègue, J., Gente, P., Rolet, J., Coussement, C., Stetter, K.O., Huber, R., Buku, S., Mifundu, W., 1993. Hydrothermal vents in Lake Tanganyika, East African Rift system. Geology 21, 499-502.

Timperly, M.H., Brown, R.J., 1986. Water chemistry of lakes in the Taupo Volcanic Zine, New Zealand. N. Z. J. Mar. Freshw. Res. 20 (2), 173-183. http://dx.doi.org/10.1080/ 00288330.1986.9516141.

Tivey, M.A., de Ronde, C.E.J., Caratori Tontini, F., Walker, S.L., Fornari, D., 2016. A novel heat flux study of a geothermally active lake - Lake Rotomahana, New Zealand. J. Volcanol. Geotherm. Res. 314, 95-109.

Walker, S.L., Baker, E.T., Resing, J.A., Nakamura, K., McLain, P.D., 2007. A new tool for detecting hydrothermal plumes: an ORP sensor for the PMEL MAPR [abs.]. EOS Trans. Am. Geophys. Union 88 (52) (Fall Meeting Supplement, Abstract V21D-0753).

Walker, S.L., Baker, E.T., de Ronde, C.E.J., Yoerger, D., Embley, R.W., Davy, B., Merle, S.G., Resing, J.A., Nakamura, K., 2008. High-resolution distribution of temperature, particle and oxidation-reduction potential anomalies from a submarine hydrothermal system: Brothers Volcano, Kermadec Arc. [abs.]. EOS Trans. Am. Geophys. Union 89 (53) (Fall Meeting Supplement, Abstract V41B-2077).

Whiteford, P.C., Bibby, H.M., 1995. The heat discharge into Lake Rotomahana, North Island, New Zealand. In: Barbier, E., Iglesias, E., Palmason, G. (Eds.), Conf. Proc. First World Geothermal Congress Florence, Italy, (1995).

Whiteford, P.C., Graham, D.J., 1993. Thermal area beneath Lake Rotomahana outlined by sediment temperature measurements. Proceedings of the 15th New Zealand Geothermal Workshop, pp. 213-217.

Whiteford, P.C., Graham, D.J., 1994. Conductive heat flow through the sediments in Lake Rotomahana, New Zealand. Geothermics 23 (5/6), 527-538. 